\title{
SCHOOL DESEGREGATION AND COMMUNITY SOCIAL CHANGE*
}

\author{
Christine H. Rossell $\dagger$
}

\section{INTRODUCTION}

Despite the fact that social science research indicates that an individual's community environment significantly influences his or her attitudes, behavior, and life chances, most research on education has ignored this factor. Educational outcomes typically have been analyzed at the school level as if schools were so many atomistic, isolated laboratories. Nevertheless, the school district community has significant, if often overlooked, relationships to its schools. ${ }^{1}$ First, and perhaps most obvious, the community creates the social atmosphere of the school. Second, about 50 percent of the funding for local schools comes from the property taxes paid by the residents of that school district. ${ }^{2}$ Thus, the level of community support and the property wealth of the residents limit the quality of education offered. Third, schools are governed at the school district level, not at the school level. Virtually all major policy decisions are made by a superintendent and staff appointed by the school board and responsible to the citizens of the whole school district.

The school district community is even more importantly related to school desegregation policy. The climate of opinion delimiting and shaping desegregation policies is created by the community. Indeed, community opposition has been successful in delaying substantial school desegregation in most school districts in the United States, particularly in the North. If school desegregation is implemented, it is usually under court order, and community social tensions and cleavages are brought into the classroom by children, their teachers, and their principals.

In addition, school desegregation plans are formulated at the district level, and the district's boundaries circumscribe the extent of pupil reassignments,

\footnotetext{
* I would like to thank Gail Thomas, Garth Taylor, Bill Hawley and Betsy Levin for their helpful comments on earlier drafts of this paper. Dwane Smith provided research assistance.

$\dagger$ Assistant Professor of Political Science, Boston University.

1. The concept of community as used in this article is a territorially organized, diverse population living in a relationship of mutual interdependence. The particular type of community analyzed here is the school district community. Its boundaries are not always identical to the city boundaries. Most Southern school districts, for example, are countywide.

2. Anvisory Commission on Intergovernmental Relations, Financing Schools and PropeRty Tax Relief-A State Responsibility 15-18 (1973).
} 
since the Supreme Court has ruled that federal courts may not mandate a school desegregation plan that crosses the political-legal boundaries of a school district, except in the unusual case of an inter-district violation, regardless of how educationally or socially rational such a move might be. ${ }^{3}$ Thus, many school districts are severely limited in their options for implementing desegregation. Furthermore, in the absence of a national plan to desegregate all school districts, individuals can choose whether to comply or evade the local desegregation plan simply by moving outside the boundaries of the school system or enrolling in a private school. If such evasion occurs on a large scale, it can significantly change community and school characteristics.

Thus, we come full circle. The community is important to school desegregation because it is an input into the classroom and its educational outcomes, and school desegregation is important to the community because it can profoundly change those inputs. This article analyzes this dynamic process through a review of current research on the subject. Unfortunately, there are few studies that systematically examine the community processes associated with desegregation as critical intervening variables that might influence outcomes, or as significant outcomes in and of themselves. ${ }^{4}$

\section{A. A Theoretical Model of Community Social Change}

School desegregation has three prominent features which, taken together, make it somewhat different from the social change usually described or analyzed by political scientists and sociologists. First, school desegregation is to a large degree social change from the top down, rather than from the bottom up. It is demanded by a small minority of the population-blacks and occasionally Hispanics-and supported by an even smaller, but potentially influential, group of elites and by the courts. The fact that school desegregation is in most instances court ordered means that it is beyond politics in the usual sense of the word. Thus, instead of the masses mobilizing and obtaining their demands, school desegregation is the result of a relatively powerless minority convincing an influential policymaking body-the courts-that desegregation is required by the Constitution. As a consequence, the white majority must be forced to comply.

Secondly, desegregation is a policy for which costs not only vary from individual to individual and class to class, as is common with most redistributive

3. Milliken v. Bradley, 418 U.S. 717 (1974).

4. A search of the social science literature yielded few studies that were relevant to this article. Most of the articles concerned with the effect of school desegregation on communities were journalistic case studies, while the more systematic analyses of racial attitudes and behavior were not related to implementing school desegregation within a community. This article reviews only those studies that dealt with desegregated school systems and used empirical data to draw conclusions. I appeal to readers to inform me of any research studies 1 may have missed, or work currently in progress, that fits the above criteria. 
policies, but differ visibly from community to community. That is, some communities are forced to desegregate while others, even though highly segregated, manage to avoid it. Therefore, many residents of a school district undergoing desegregation feel extraordinary resentment because they are bearing costs not borne by other communities. Moreover, since communities are not isolated from the nation at large, community social change is cross pressured $^{5}$ by the influence of that portion of the larger society that has not undergone any substantial school desegregation and is making every attempt to see that future busing for school desegregation is prohibited.

Finally, school desegregation is a policy whose goal is not simply behavioral compliance, but a change in attitude of the most fundamental kind-how one feels about one's self, one's identity, one's place in society, and the value of other individuals, their identity, and their place in society. No matter how much behavioral compliance is obtained, school desegregation will not be successful until it obtains this fundamental attitudinal change.

There are virtually no theories of social change that are applicable to this particular type of "forced" community social change. Although psychologists have attempted to analyze attitudinal change systematically from perspectives like balance theory, consistency theory, and cognitive dissonance theory, ${ }^{6}$ they have not attempted to link these investigations to the real world of public policies and community or group social change where the stimuli are much more diffuse and cross pressured than in the laboratory. Political scientists have analyzed behavioral compliance with judicial decisions, but they have rarely tried to relate this to attitudinal change. ${ }^{7}$

5. Cross pressure refers to a social situation in which an interpersonal conflict arises when the motives affecting a decision are incompatible. The cross pressure hypothesis applies mainly to situations of social or political conflict.

6. Consistency theory is based on evidence that people need consistency in terms of value in their attitudes, beliefs, and behaviors-that is, a consistency of evaluated meaning derived from ideas and associations. Awareness of one's own inconsistency is viewed as an uncomfortable situation that everyone is motivated to escape. The need for a psychological consistency often overrides the concern for strict logical consistency. A related theory is balance theory, which states that people tend to maintain consistency between unit relationships (e.g., ownership, kinship, membership) and sentiment relations (e.g., dislike, love, approval). Cognitive dissonance theory. on the other hand. involves both connotative and denotative meaning. Cognitive elements-items of knowledge consisting of beliefs about oneself, the environment, and one's behavior-may form consonant, dissonant, or irrelevant relationships. People strive, consciously or unconsciously, to relieve the tension caused by dissonant relations. J. Tedeschi \& S. Lindskold, Social PsycholoGy 199, 198-220 (1976). See also note 9, infra.

7. K. Dolbeare and P. Hammond, The School Prayer Decisions: From Court Policy to local Practice (1971); H. Rodgers and C. Bullock, Law and Social Change: Civil Rights Laws and Their Consequences (1972); S. Wasby, The Impact of the Supreme Court: Some Perspectives (1970); $R$. Johnson, The Dynamics of Compliance: Supreme Court Decision-Making From a New Perspective (1967). The following two works have examined the effect of law on attitudinal change, but have not done so with rigorously scientific methods: W. Muir, Prayers in the Public Schools: Law and Atritude Change (1967); H. Rodgers, Community Conflict, Public Opinion and the Law (1969). 
In describing the prominent features of a theory of forced community social change that involves not just behavioral change but also attitudinal change, I begin with the assumption that school desegregation, if it is defined as the busing of school children for the purpose of "racial balance," "school desegregation," or "school integration," is not accepted by a large proportion of the white population. ${ }^{8}$ The social psychological literature on dissonance theory suggests that individuals have a need to obtain consistency between such cognitive elements as items of knowledge, information, attitude, or beliefs-as well as between attitudes or beliefs on the one hand, and behavior on the other. ${ }^{9}$ Individuals try to avoid information or situations that will increase dissonance. If they are in contact with or experiencing something with which they do not agree, they either rid themselves of the experience or come to believe in it.

Phase I. The decision to implement a policy of school desegregation initiates the first phase of social change. If individuals feel there is some hope of success, they will attempt to rid themselves of an experience they perceive as disagreeable and likely to produce dissonance. At the community level, this is manifested as controversy because, as with virtually all racial or civil rights issues, some individuals or groups will not find desegregation inconsistent with their beliefs. That is, there will be many, particularly blacks, who will want the schools to be desegregated. If desegregation is court ordered, there will be those who, regardless of their personal beliefs about desegregation, feel that such decisions made by a legitimate and powerful policymaking body ought to be obeyed. Ad hoc groups will form based on these divisions, and controversy may result in group protest demonstrations at this stage if the community environment is conducive to it.

This first stage of social change may also be characterized by individual actions, which are less discordant, but whose goal is essentially the same as group protest: to rid the community or the individual of the disagreeable experience. This may include protest voting-attempts to throw the policymakers out of office either because they are responsible for the school desegregation decision or because it is felt they should not have complied with the court order. When political action appears to have no effect, some people

8. A 1976 Harris Poll shows only $9 \%$ of whites and $38 \%$ of blacks favor busing school children to achieve racial balance. Harris Polls Press Release (July 8, 1976). Nevertheless, according to a 1976 survey by the National Opinion Research Center at the University of Chicago, whites are overwhelmingly in support of the principle of school racial integration (83\%). Taylor, Sheatsley, \& Greeley, Periods of Change in American Racial Attitudes, 238 Scientific AM. June 1978, at 42.

9. See, e.g., L. Festinger, A Theory of Cognitive Dissonance (1975); J. Brehm \& A. Cohen, Explorations in Cognitive Dissonance 269-285 (1962); L. Festinger, Conflict, Decision, and Dissonance (1964); C. Kiesier, B. Collins, \& N. Miller, Attitudinal Change: A Critical Analysis of Theoretical Approaches 191 (1969); S. Oskamp, Attitudes and Opinions 191221 (1977); Festinger \& Carlsmith, Cognitive Consequences of Forced Compliance, 58 J. ABNormaL \& Soc. Psycr. 203 (1959) [hereinafter cited as Festinger \& Carlsmith]. 
will exit from the public schools in order to avoid the experience. Because school desegregation is implemented only within the public school system's boundaries, it is relatively easy for some families to avoid compliance with the policy of school desegregation, although the perceived legitimacy of the court and the options for noncompliance will also enter into this decision. Moreover, since the tangible costs of noncompliance are primarily monetary, rather than punitive, a class-differentiated burden is created, which exacerbates community controversy and polarization.

Phase II. What makes school desegregation unique compared to other national policies is that virtually everyone who continues to reside in the community, regardless of whether he has children in the public schools, will, to one degree or another, participate in the experience through the media, neighborhood discussions, leadership statements, and social organization discussions or activities. Hence, all community residents will be faced with a new cognitive situation, although its characteristics will vary according to prior individual beliefs, other personal characteristics, and the nature of the desegregation stimuli. This is the second phase of social change. The forced compliance paradigm of cognitive dissonance theory indicates that individuals who are forced to comply with this counterattitudinal behavior will try to reduce cognitive dissonance by changing their attitudes in the direction of liking the experience. ${ }^{10}$ According to this paradigm, forced school desegregation should result in a reduction in prejudice against the other race and an increase in support for integration. ${ }^{11}$

However, the nature of the first phase of social change, community reaction to the decision to desegregate, may be crucial to the outcome of the second phase of change-a reduction in prejudice. A critical element in dissonance theory is that the greatest amount of attitudinal change will come about when the pressure put upon the individual is the least, and when there is some element of choice involved in the behavior. ${ }^{12}$ It follows that if there is a great deal of protest, violence, and white flight, the forced element of school desegregation will be perceived as great and thus the amount of desired attitudinal change presumably will be less. Moreover, there is likely to be a class difference in the perception of compulsion with the working class more likely to perceive greater compulsion and thus less likely to undergo the desired attitudinal change. On the other hand, this may be offset by more unfavor-

10. See Festinger \& Carlsmith, supra note 9; Brehm \& Cohen, supra note 9.

11. In sociology this has been called the "fait accompli theory." As Pettigrew puts it, "desegregation itself brings its own fait accompli acceptance... public opinion accommodating itself to the new arrangement after the fact." Pettigrew, Continuing Barriers to Desegregated Education in the South, 38 Soc. Educ. 99, 109 (1965).

12. See Festinger \& Carlsmith, supra note 9; Linder, Cooper, \& Jones, Decision Freedom as a Determinant of the Role of Incentive Magnitude in Attitude Change, $6 \mathrm{~J}$. Personality \& Soc. PsYch. 245 (1967). 
able attitudes on the part of the working class. The more unfavorable a person's attitudes toward an event or position, the more dissonance he or she will experience when the event occurs. ${ }^{13}$

Greater attitudinal change is likely to occur when the foregoing conditions are satisfied and the individual feels there are unpleasant consequences of complying with school desegregation policies. ${ }^{14}$ Given the fears many parents have about school desegregation, it is not unreasonable that, having complied, some parents force themselves to believe that the decision to comply was correct. Nevertheless, they have to view this decision as binding. It is possible that extraordinary conflict and violence associated with implementation may delay this perception. This is significant, inasmuch as nonbinding or revocable decisions do not produce cognitive dissonance. Indeed, under such conditions there may be boomerang effects that will strengthen the person's racial prejudices. ${ }^{15}$

Thus, the process of social change is extremely complex. That there will be some attitudinal change can be predicted, but how much or when, or even if the change will be greater over time cannot. This is not only because of the above factors, but also because the stimulus to change one's attitudes is indirect-it is the children of the community who are desegregated, not the adults. The process is actually a reciprocal one, whereby adult attitudes and opinions are influenced by their children's perceptions of their experiences and vice versa. The children's perceptions may also be related to the first phase of social change, the adult reaction to the decision to desegregate.

The complexity of this process suggests that the time dimension may be extremely important in evaluating the success of school desegregation. AIthough laboratory experiments are able to accomplish almost immediate attitudinal changes, the subjects involved in these experiments volunteered to participate. That element is missing in most communitywide school desegregation "experiments," and the complex and cross-pressured environment of a community may be such a weak stimulus that the desired effect may never be seen. It is also conceivable that the original element of force or coercion has to be forgotten before any significant change in attitude can take place.

Phase III. The last phase of the theory of social change outlined here is

13. This is a function of a whole host of attitudes on desegregation and the legitimacy of the courts. as well as the fact that the middle class is more able to afford the move to the suburbs or to private schools and thus more likely to see complying with school desegregation as a matter of choice.

14. See Brehm \& Cohen, supra note 9, at 273. Collins \& Hoyt, Personal Responsibility-forConsequences: An Integration and Extension of the "Forced Compliance" Literature, $8 \mathrm{~J}$. ExPERIMENTAI. Soc. Psrch. 558 (1972); Kiesler \& Munson, Attitudes and Opinions, I Anv. Rev. Soc. 26, 415456 (1975).

15. Kiesler, Commitment, in Theories of Cognitive Consistency 448 (1968); Brehm \& Cohen, supra note 9, at 278 . 
characterized by positive attitudinal changes resulting in other positive behavioral changes beyond sending one's child to an integrated school. The behavioral changes that can be measured within a relatively short period of time are electoral and residential. That is, school desegregation might be followed by the election of black officials and defeat of antibusing candidates and by an increase in residential integration. This hypothesis is based on cognitive dissonance theory, described above, and contact theory. The contact hypothesis suggests that if blacks and whites come into equal status contact with each other through parent-school organizations and other school-related activities, they will come to treat each other as equals, and there will be a reduction in racial discrimination. ${ }^{16}$

Nevertheless, the evidence on congruence of attitude and behavior indicates that even if school desegregation is able to bring about a change in attitudes, it may not be sufficient to change behavior in all activities. In order for attitudes to cause a change in behavior, external stimuli may be necessary. Such stimuli as perceived reference group support for a particular form of behavior and immediate social pressure can cause a change in behavior that is either congruent or incongruent with attitudes. ${ }^{17}$ Incentives may also be able to change behavior. For example, citywide school desegregation plans involving busing could be an incentive for residential integration. This hypothesis is based on the fact that most white Americans support the principle of school integration, ${ }^{18}$ but not busing for racial balance. ${ }^{19}$ A significant proportion of blacks also oppose busing for desegregation. ${ }^{20}$ In addition, whites are less opposed to bringing minority children into their own schools than they are to sending their children across town to ghetto schools. ${ }^{21}$ Therefore, a citywide

16. G. Allport, The Nature of Prejudice (1954); Cook, Motives in a Conceptual Analysis of Attitude-Related Behazior, in Nebraska Symposium on Motivation 1969, at 179 (1969); Weigel, Wiser, \& Cook, The Impact of Cooperative Learning Experiences on Cross-Ethnic Relations and Attitudes, $31 \mathrm{~J}$. Soc. Issues, Winter 1975 , at 219.

17. M. Fishbein \& I. Ajzen, Belief, Atritude, Intention and Behavior (1975); Brannon, Cyphers, Hesse, Hesselbart, Keane, Schuman, Viccaro \& Wright, Attitude and Action: A Field Experiment Joined to a General Population Survey, 38 Ам. Soc. Rev. 625 (1973); Wicker. Attitudes Versus Actions: The Relationship of Verbal and Overt Behavioral Responses to Attitude Object, $25 \mathrm{~J}$. Soc. Issues, Autumn 1969, at 41. Many studies have shown that behavioral intentions are usually good predictors of overt behaviors. See Fishbern \& AJzen, supra at 373; and Kothandapani, Validation of Feeling, Belief, and Intention to Act as Three Components of Attitude and Their Contribution to Prediction of Contraceptive Behavior, $19 \mathrm{~J}$. Personality Soc. Psych. 321 (1971); Schuman \& Johnson, Attitudes and Behavior, 2 A NN. Rev. Soc. 161, 188 (1976).

18. See G. Orfield, Must We Bus? Segregated Schools and National. Policy 108-09, 274 278 (1978).

19. Id. at 109-118, 233-278.

20. Harris Polls Press release (July 8, 1976).

21. Busing of Schoolchildren: Hearings on S. 1651 Before the Comm. on the Judiciary, 95th Cong., 1st Sess. 159 (1977) (declaration of David J. Armor, exhibit B); Lord, School Busing and White Abandonment of Public Schools, 15 Southeastern Geographer 81 (1975) thereinafter cited as Lord]; Giles, Racial Stability and Urban School Desegregation (forthcoming in URB. AFF. Q.) 
busing plan where integrated neighborhoods are excluded from busing would provide an incentive for residential integration. Blacks might be willing to move into all white neighborhoods if it meant their children could go to the neighborhood schools, rather than being bused across town. Moreover, the receiving neighborhood might be more amenable to such in-migration if it meant its residents would be excluded from any busing plan. In short, school desegregation might produce desegregated residential neighborhoods because it changes attitudes and because it provides an incentive for congruence of attitude and behavior.

\section{B. The Policy Implications}

The various phases of this process of community social change are summarized below. For each of the phases of individual attitudinal change derived from cognitive dissonance theory, there are community or group manifestations. Although no single research study has attempted to analyze and integrate all of these community manifestations in terms of a process of social change, it is possible to analyze the individual studies and draw out of them information that is both theoretically and practically relevant.

Theoretical Phases of Individual Attitudinal Change

\section{Community/Group Manifestation}

Attempt to rid community and individual of undesired experience.

Individual attempt to avoid undesired experience.

Attempt to change one's evaluation of experience.

Attempt to achieve congruence between attitudes and behavior in complex cross-pressured enGroup protest demonstrations, individual protest voting.

"White flight."

Pro-integration attitudinal change, reduction in prejudice. Election of blacks, residential integration.

vironment where individuals are pro-integration but antibusing.

In policy analysis terms, the attempt to rid the individual or the community of the disagreeable experience in the first stage of social change results in

[hereinafter cited as Giles]; Pride \& Woodward, Busing Plans, Media Agenda, and White Flight: Nashville and Louisville (April 12-15, 1978) (paper presented at the annual meeting of the Southwestern Political Science Association, Houston, Texas) [hereinafter cited as Pride \& Woodward]; C. Rossell, Assessing the Unintended Impacts of Public Policy: School Desegregation and Resegregation (1978) (report prepared for the National Institute of Education) [hereinafter cited as Rossell, Unintended Impacts]. 
negative consequences for community social change, which are the indirect costs of the policy. The degree to which school desegregation influences people to have less prejudiced attitudes and to act in a less prejudiced manner are the benefits of the policy. Presumably, the greater the costs, the smaller the net benefit.

The remainder of this article is organized according to the communitygroup manifestations of social change outlined above. For each of the four categories-group protest and individual protest voting, white flight, attitudinal change, and residential integration-the characteristics of that phase of social change, how school desegregation variations can influence variations in the community phenomenon, and how the phenomenon can influence the classroom environment are analyzed. Information that provides insights into how to make the school desegregation process more successful in achieving its goals is stressed, meaning that the bad news is given equal time with the good news.

\section{I}

\section{Group Protest Demonstrations and Protest Voting}

The characteristics of protest demonstrators and the community environment necessary for protest, the characteristics of protest voting, and the effect of protest demonstrations and voting on school desegregation outcomes are described in this section. This is the first phase of social change-the attempt to rid the community of the impending implementation of school desegregation. While school desegregation provokes some degree of controversy in virtually all communities, significant protest occurs only in certain communities.

\section{A. Characteristics of Protest Demonstrators}

While there have been numerous studies of the characteristics of individuals opposed to school desegregation, little systematic research has been conducted on those who actually participate in protest activity. The analysis of protest, because it is a form of political participation, poses a dilemma. On the one hand, the research findings suggest that those most opposed to school desegregation are lower-class, uneducated, racist, and Southern. On the other hand, the political participation research indicates that those of higher social status tend to participate more than others in political activity.

The findings of four studies that analyze systematically the individual characteristics of protesters reflect this dilemma. A study of seven Florida county school districts, by Giles, Gatlin, and Cataldo, found that among those who complied with the desegregation plan, the proportion of protesters increased with higher income, educational level, and occupational prestige, and that there was little difference between Southerners and Northerners. ${ }^{22}$ No

22. M. Giles, D. Gatlin, \& E. Cataldo, Determinants of Resegregation: Compliance/Rejection 
other study has found this to be the case. A study of Indianapolis desegregation, for example, found no direct or indirect relationship between protest and such background factors as sex, income, and education. ${ }^{23}$

A quasi-experimental ${ }^{24}$ study of Boston's school desegregation process, originally designed by Ross and Friedman,${ }^{25}$ has been analyzed by Ross, and in a separate study, by Taylor and Stinchcombe. Taylor and Stinchcombe found Catholics, less educated individuals, and younger people more likely to be mobilized for boycotts. ${ }^{26}$ A survey of Louisville-Jefferson County by McConahay and Hawley found that those in the upper working class (with high school degrees) were more likely to protest than either those with the least education or those with the most. In addition to this curvilinear relationship between class and participation in protest activity, their data suggest that while in general the working class is more involved than the middle class in protest activity, the leaders tended to come from the middle class. ${ }^{27}$ Moreover, the middle class participates at a much higher rate than the popular description of protestors would have led us to expect.

Behavior and Policy Alternatives IV-1-IV-18 (June 1976) (report to the National Science Foundation, NSF/RA-760179) [hereinafter cited as Giles, Gatlin, \& Cataldo]. Part of the reason for their different finding is that the authors in their definition of protest the direct contact of of ficials and signing of petitions.

23. Hayes, Anti-Busing Protest 8 (Nov. 1977) (paper presented at the annual meeting of the North Carolina Educational Research Association) [hereinafter cited as Hayes].

24. A quasi-experimental design is used when the circumstances are such that true experimental design, with random assignment of persons to treatment and "control" situations, is not possible. A quasi-experimental design fulfills three of the four conditions of an experimental design: a "test" (or observation) obtained before the treatment, a "test" (or observation) obtained after the treatment, and a control group whose pre- and post-treatment observations (without having undergone the treatment) are compared to those of the treatment group. There is no random assignment to treatment and control groups as in a true experiment. An interrupted time series experiment uses a series of measurements providing multiple pre- and post-"experimental treatment" observations. In quasi-experimental analysis, the change noted can be ascribed to the "experimental treatment" if adequate consideration is given to plausible alternative explanations. D. Campbell \& J. Stanley, Experimental and Quasi-Experimental Designs for Research (1966); Campbell \& Ross, The Connecticut Crackdown on Speeding: Time Series Data in Quasi-Experimental Analysis, 3 LAw \& Soc. Rev. 33 (1968). See also Levin, Education, Life Chances, and the Courts: The Roles of Social Science Evidence, 39 Law \& Contem. Prob., Spring 1975, at 217, 218-220.

25. Ross \& Friedman, Protest Politics and School Desegregation (1973) (proposal submitted to the National Institute of Education).

26. D. Taylor \& A. Stinchcombe, The Boston School Desegregation Controversy 100-102 (1977) (unpublished manuscript. National Opinion Research Center) [hereinafter cited as Taylor \& Stinchcombe]. For a more complete analysis see works by J. Michael Ross, Boston University Center for Applied Social Science Research. See also J. Ross \& W. Berg. The Social Construction of a School Desegregation Controversy: A Crisis of Law in Society (1978); J. Ross \& W. Berg, The Boston School Desegregation Crisis: A History and Narrative Account (1977) [both works hereinafter cited as Ross \& Berg]. At the time this article was written, the Ross \& Berg studies were not available.

27. McConahay \& Hawley, Attitudes of Louisville and Jefferson County Citizens Toward Busing for Public School Desegregation: Preliminary Results (July 1976) (unpublished paper, Duke University Institute of Policy Sciences and Public Affairs) [hereinafter cited as McConahay \& Hawley, Preliminary Results]; unpublished data from the Louis Harris and Associates survey for the Institute of Policy Sciences and Public Affairs at Duke University. 
All four studies found participation in protest activities related to feelings of anomie and authoritarianism, as well as to racial prejudice and opposition to school desegregation. One study also found participation in protest related to class prejudice. ${ }^{28}$

\section{B. Protest Demonstrations and the Community Environment}

Virtually all of the studies are in agreement that protest, because it is a deviant form of behavior, needs a supportive environment in order to manifest itself. Like others who engage in deviant acts, the potential protester must go through a series of redefinitions of the situation before the act of protest is perceived as legitimate by him or her.

An early study (1960-68) of ninety-one Northern cities found white opposition as expressed through protest, picketing, attendance at school board meetings and other kinds of demonstrations to be greatest in cities where blacks were inactive, where the mayor was conservative, and where opposition to desegregation came from within the school board itself. ${ }^{29}$ Two later studies clarify this relationship. The Hayes study of Indianapolis ${ }^{30}$ and the Taylor and Stinchcombe reanalysis ${ }^{31}$ of Ross's study of Boston found the perception of social support, especially neighborhood support, to be strongly related to protest activity. Moreover, in Boston, the social network within the Catholic Church played a significant role in strengthening people's opinions and propensity to protest. $^{32}$

The characteristics of the particular desegregation plan appear, in part, to create an environment supportive of protest. A study of ten cities undertaken by the author, analyzing newspaper coverage of schools during the year preceding the implementation of court-ordered desegregation, found that at the aggregate level, protest is positively related to the extent of white student reassignments to formerly black schools. The greater the proportion of white students reassigned, the greater the extent of protest activity. ${ }^{33}$ It is likely that with

28. Giles, Gatlin, \& Cataldo, supra note 22.

29. D. Kirby, T. Harris, \& R. Crain, Political Strategies in Northern School DesegreGation 128-130 (1973) [hereinafter cited as Kirby, Harris, \& Crain].

30. Hayes, supra note 23 , at 9-10.

31. Taylor \& Stinchcombe, supra note 26.

32. See Ross \& Berg, supra note 26.

33. Rossell, The Effect of Community Leadership and the Mass Media on Public Behavior, 8 ThEORY Into Practice, April 1978, at 134 [hereinafter cited as Rossell, Public Behavior]. The protest variable is the sum of ordinal rankings of the age group of the participants, their race, the type of protest (e.g., rally, sit-in, march, boycott) plus the number of days the protest activity took place, the number of participants involved, the number injured, arrested, and killed. (The type of protest is assigned a number based on a ranking in which a rict is the worst, and a protest rally the least.) The number of protest demonstrations, the average severity (based on the above mean score), and the total score for the same period were calculated for three month periods during the school year prior to the implementation of a school desegregation plan. 
extensive, two-way busing plans, entire white neighborhoods would be affected, and thus united in their opposition to having their children bused out.

An important finding of this ten-city study is that during the year preceding the implementation of court-ordered desegregation, traditional methods of leadership support-for example, public pronouncements for or against school desegregation-had little effect on protest. Indeed, protest seems to have caused leaders to make negative pronouncements on school desegregation rather than the reverse. ${ }^{34}$ On the one hand, this appears to support the Indianapolis and Boston studies. ${ }^{35}$ Public statements by city leaders are likely to be ineffective because such techniques rarely influence the neighborhood environment of social support. On the other hand, this finding may be attributable to the fact that there were few leadership statements one way or the other. Most leaders hid from the issue, and the only positive statements about school desegregation made by city leaders were in response to negative statements by other leaders.

It is interesting to note that there was a distinct tendency for leadership statements in support of desegregation to be negatively related to the extent of the desegregation plan-the less the desegregation, the more positive the statements by leaders. ${ }^{36}$ Therefore, studies that find leadership support of school desegregation to facilitate peaceful implementation may be misleading because they failed to control for the extent of the desegregation plan. ${ }^{37}$

Still, in the absence of any strong city leadership support of school desegregation plans that require extensive busing, it is difficult to say that such support would have no effect on minimizing protest and violence. All that can be said is that there is no conclusive evidence either way. However, one can hypothesize that in the face of neighborhood-based opposition to desegregation, traditional centralized leadership is likely to be ineffective. The corollary to this is that the greater the influence prodesegregation elites have on neighborhood opinion leaders, the less the protest against school desegregation.

\section{Protest Voting}

Only two studies have specifically examined the impact of the process of implementing school desegregation on local elections, and both generally substantiate the principles of alienation theory, although with a new twist. Both studies-one a precinct analysis of Lansing, Michigan, ${ }^{38}$ the other a sixty-nine

34. Id. at 134-35. The extent of desegregation was statistically controlled to determine the independent effect of leadership.

35. Hayes, supra note 23; Taylor \& Stinchcombe, supra note 26

36. Rossell, supra note 33 , at 133.

37. D. Kirby, T. Harris, \& R. Crain, supra note 29; U.S. Comm'n on Civil Rights, Desegregation of the Nation's Public Schools, Fulfiling the Letter and Sirit of the Law 126 (1976).

38. Lezotte, Voter Behavior as an Expression of Community Attitudes Toward Desegregation 
school district comparative analysis ${ }^{39}$-are quasi-experimental. They indicate that the voter turnout for school elections decreases in school districts that desegregate under court order and that there is no change in dissent voting. The decrease in turnout presumably is a function of the fact that in such a situation individuals feel they have no control over school policy; that is, they are alienated.

In non-court-ordered desegregation, the more extensive the school desegregation plan, the more dissent voting in both school board elections and tax referenda, and the higher the voter turnout. Presumably this relationship is due to the fact that the more extensive the plan, the more controversial and more publicized becomes school desegregation. This attracts dissenting voters to the polls to register a complaint. In addition, dissent voting is greatest in school districts where educational levels are low, ${ }^{40}$ undoubtedly because such voters are more likely to oppose school desegregation and busing and be alienated on a number of such "liberal" issues.

While dissent voting is temporary (occurring immediately after the school desegregation decision is made and only rarely continuing past the first year in which the plan is implemented), increased voter turnout for school board elections is permanent in school districts where educational levels are high, where there has been extensive, but non-court-ordered desegregation. ${ }^{41}$ Thus, in these communities the long term impact of non-court-ordered school desegregation is to stimulate political participation.

\section{Protest as an Intervening Variable}

If protest demonstrations and protest voting are positively correlated with the extent of the desegregation plan, it follows that protest is not effective in preventing desegregation. Demonstrations begin after the decision to desegregate has been made-sometime during the middle of the school year before the plan is implemented-and build to a peak during the week the schools open. They rarely continue past the year in which the plan is implemented. ${ }^{42}$ Protest voting exhibits a similar pattern, although it will occasionally continue after the implementation year. ${ }^{43}$

\footnotetext{
(April 1976) (paper presented at the annual meeting of the American Educational Research Association, San Francisco, California).

39. Rossell, The Political and Social Impact of School Desegregation Policy: A Preliminary Report (Sept. 1975) (paper presented at the annual meeting of American Political Science Association, San Francisco, California) [hereinafter cited as Rossell, Preliminary Report].

40. Rossell, Preliminary Report, supra note 39.

41. Id.

42. See Kirby, Harris, \& Crain, supra note 29, at 125-132; Rossell, Public Behavior, supra note 33 .

43. Rossell, Preliminary Report, supra note 39.
} 


\section{Protest Demonstrations}

While there is no evidence that protest is effective in preventing school desegregation, demonstrations can have serious negative effects on desegregation outcomes in two ways. First, there is some evidence that they may have an independent effect on white flight. One study has shown that the degree of white flight is positively related to the level of protest in the first six months of the school year before the desegregation plan, regardless of the extent of the desegregation plan. ${ }^{44}$ Thus, protest may drive out the additional white enrollment needed for adequate interracial contact to insure the success of the school desegregation plan.

Second, protest can have a serious negative effect on student behavior in the schools and ultimately on educational outcomes. In Pontiac, Michigan, the drop in the number of student incidents was observed to coincide with the decline in adult protest against the desegregation plan. ${ }^{45}$ Similarly, the Boston Globe charted the daily student attendance in the Boston school system during the first year of the implementation of the school desegregation plan (19741975), and showed that sharp drops in attendance followed street disturbances. ${ }^{46}$ And as indicated in a 1975 review of school desegregation research, community racial conflict and student disturbances reduce the likelihood of minority achievement gains in desegregated schools. ${ }^{47}$

\section{Protest Voting}

The fact that protest voting is positively correlated with the extent of desegregation indicates that, like demonstrations, it is not very effective in preventing implementation. A study of sixty-nine urban school districts showed that in only one, Rochester, New York, did the defeat of the incumbent school board members in regular or recall elections actually result in a desegregation plan's being permanently rescinded. ${ }^{48}$ The Denver, Lansing, and Detroit school districts' defeat of the incumbent school board members resulted in the plan's temporary rescission, only to have it later ordered into effect by a federal court. ${ }^{49}$ Ironically, the district court in the Denver case

44. The partial correlation was .49 when the extent of desegregation was controlled. A partial correlation is the correlation between two statistical variables under the condition that all other relevant variables are fixed. See Rossell, Public Behavior, supra note 33.

45. U.S. Comm'n on Civil Rights, School. Desegregation in Ten Communities 21 (1973). [quoting a Pontiac school official].

46. Richard, Knox, \& Oliphant, The First Year, Boston Globe, May 25, 1975, \& A, at 12, col. 1.

47. Weinberg, The Relationship Between School Desegregation and Academic Achievement: A Review of the Research, 39 LAw \& Contemp. Prob., Spring 1975, at 240. This relationship is also examined in Felice, Mandatory Busing and Minority Student Achievement: New Evidence and Negative Results (Sept. 1975) (paper presented at the 1975 American Sociological Association Meeting, San Francisco, California).

48. Rossell, Unintended Impacts, supra note 21.

49. Keyes v. School Dist. No. 1, 380 F. Supp. 673 (D. Colo. 1974); NAACP v. Lansing Bd. of 
noted that the rescission of the previous board's plan by the newly elected antibusing board was evidence of intentional segregation. ${ }^{50}$

There are several reasons why dissent voting fails to prevent the implementation of desegregation plans. First, like demonstrations, dissent voting is a reaction, not an initiative. Since board elections usually are held only on predetermined dates, board election dissent voting typically occurs after the implementation of the plan. It is much more difficult to rescind a plan that has already been adopted. Second, the decision to desegregate is obviously made in response to the presence of segregated schools. Therefore, if the board plan is rescinded, there is a high probability that a court will see the same segregation and be able to find some intentional aspect to it. If the dissent voting is in response to a school board's failure to appeal a court decision (for example, the Pasadena recall election of 1970), there is little evidence to suggest that an appeal taken by a new antibusing school board will be successful. Finally, like demonstrations, protest voting is temporary. Therefore its effect on the composition of the school board is significant only if there is a successful recall election.

\section{E. Summary}

The research on protest indicates that the following propositions characterize this stage of social change:

1. Protest occurs after the decision to desegregate has been made and rarely continues past the implementation year.

2. The greater the proportion of whites reassigned to formerly black schools, the greater the degree of protest.

3. Participation in protest demonstrations has a curvilinear relation to socioeconomic status. ${ }^{51}$

4. The leaders of protest demonstrations tend to be middle-class.

5. Protest demonstrations are dependent on a supportive environment, particularly at the neighborhood level. Moreover, there is no evidence that traditional techniques of leadership influence (e.g., public pronouncements, use of the mass media) would reduce the level of protest.

6. Court-ordered desegregation results in a decrease in the voter turnout for board elections and no change in dissent voting.

7. Increased board election turnout appears to be permanent in high edu-

Educ., 429 F. Supp. 583 (W.D. Mich. 1976); Bradley v. Milliken, 411 F. Supp. 937 (E.D. Mich. 1975 ).

50. Keyes v. School Dist. No. 1, 303 F. Supp. 279, 285 (D. Colo. 1969). The Tenth Circuit, affirming the finding of intentional segregation in a portion of the school district, found it unnecessary to decide whether the rescission "was also an act of de jure segregation." $445 \mathrm{~F} .2 \mathrm{~d}$ 990, 1002 (10th Cir. 1971).

51. In other words, protestors are more likely to come from the upper working class rather than from the lower class or the middle class. 
cational level school districts that have implemented extensive desegregation but not under court order.

According to the research on the subject, protest can have the following effects on school desegregation and its outcomes:

1. Neither protest voting nor protest demonstrations are effective in preventing school desegregation once the decision has been made.

2. Student disturbances within the schools and declines in student attendance accompany adult protest demonstrations.

3. Protest demonstrations increase the amount of white flight from public schools.

\section{WhITE Flight}

The ineffectiveness of protest demonstrations and protest voting in preventing desegregation, once the decision has been made, will force some individuals to attempt to avoid the undesirable experience even though the community is still forced to undergo it. In effect, these individuals are jumping ship. Nevertheless, one cannot predict the extent of this avoidance from the extent of community opposition to school desegregation or to busing. Such avoidance depends not only on attitudes, but also on the availability of options for avoiding desegregation and the costs of avoidance relative to the perceived costs of compliance. These costs will vary greatly in relation to the characteristics of the plan and among different segments of the population.

This section of the article describes (1) the effect of school desegregation on residential out-migration and in-migration, (2) the effect of desegregation on white public school enrollment in the year of implementation of the plan, (3) the causes of variations in this effect, (4) the long term effect of desegregation on white enrollment, and (5) the ability of desegregation to achieve the instrumental goal of interracial contact.

One way of determining the effect of desegregation on white flight is to conduct a survey of predesegregation attitudes toward racial integration issues, behavioral intentions with regard to moving or withdrawing children from the public schools (in the absence of any knowledge of future desegregation), and postdesegregation measures of attitudes, behavioral intentions, and actual behavior. The only such study that exists is a case study of Boston ${ }^{2}$ which, although well designed, is not yet completed and which, because of the peculiarities of Boston and the original goals of the study, may be limited in its generalizability. The costs of a comparative study of several urban school districts, using such a methodology, would be astronomical. Thus, the comparative studies that are available are aggregate analyses, and the surveys are postimplementation case studies.

52. See J. Ross, Reaction to Court Ordered Desegregation (1975) (unpublished paper). 


\section{A. Residential Out-migration and In-migration in Response to} School Desegregation

White flight from the public schools can take two forms: the transfer of students to private schools and the movement of families out of the school district. The former is obviously less damaging to a community than the latter, in part because the possibility of returning to the public schools is much greater, but also because these individuals will remain a part of the community and presumably a part of whatever social change occurs. Unfortunately, most of the research makes no distinction between the two forms of white flight. There are, however, four case studies that are able to make this distinction because of their use of survey sampling techniques. These studies indicate that there is little residential relocation in response to school desegregation. Three of the studies are of countywide plans, so this finding should not be surprising. Only 0.2 percent of the Charlotte-Mecklenburg county school population moved to neighboring Union county. ${ }^{53}$ Two studies of Louisville found little residential relocation, but their analyses were only of the postimplementation years. ${ }^{54}$ Since white flight is greatest in the implementation year, this may underestimate the amount of residential relocation that occurred, although it reveals useful information about the long term impact.

The most important of these studies, because of its implications for central city school desegregation, is the Taylor and Stinchcombe study of Boston. These researchers show that individuals who moved out of the city after desegregation tended to have the same demographic characteristics as those who would ordinarily move to the suburbs-primarily renters, young people, those without children, and those who had resided in their neighborhood for less than three years. There was no association between moving out of the city and various racial and school desegregation attitudes, either before or after demographic characteristics were taken into account. ${ }^{55}$ This analysis suggests

53. Lord, supra note 21.

54. McConahay \& Hawley, Attitudes of Louisville and Jefferson County Citizens Toward Busing for Public School Desegregation: Results from the Second Year 23-24 (Sept. 1977) (unpublished paper, Duke University Institute of Policy Sciences and Public Affairs) [hereinafter cited as McConahay \& Hawley, Second Year]; Johnson, The Impact of Court Ordered Desegregation on Student Enrollment and Residential.Patterns in the Jefferson County, Kentucky Public School District, An Interim Report (1977) (unpublished report, Louisville) [hereinafter cited as Johnson]. See also Cunningham, Husk, \& Johnson, The Impact of Court Ordered Desegregation on Student Enrollment and Residential Patterns (White Flight) (March 1978) (paper presented at the annual meeting of the American Educational Research Association, Toronto, Canada).

55. Taylor \& Stinchcombe, supra note 26, at 65-67. There is some logical reason for assuming little white flight to the suburbs will occur among homeowners, since the short term difficulty of selling one's house and getting the best price in such a situation would seem to be great. Nevertheless there could be a greater than normal outflow of renters who would have ordinarily decided to stay in the city and buy houses that could be unrelated to desegregation attitudes. The Taylor and Stinchcombe analysis gives no information on this. It should be noted that the more complete Ross analysis, supra note 52, may disagree with their findings. The Ross and Berg study, The Social Construction of a School Desegregation Controversy: A Crisis in Law and Society, supra note 26 , comes to different conclusions. 
that school desegregation does not contribute to the further deterioration of inner cities by accelerating the suburbanization of those individuals opposed to school desegregation. If there is white flight, it is at an increased rate for the entire white population. Such an increase could still be a true desegregation effect, but it might also be merely a speeding up of already formulated plans to move out of the city.

The conclusions of two aggregate studies of the effect of school desegregation on white suburbanization are unreliable since both analyzed change during the period from 1960 to $1970 .^{56}$ There was very little desegregation during this time period and virtually no mandatory reassignments of white students.

Equally as important as white flight is the problem of nonentrance. Studies of residential turnover, for example, have found that while neighborhoods changing from predominantly white to predominantly black often do not have higher rates of white out-migration than other areas, they do have a drop in white in-migration. ${ }^{57}$ In other words, whites are not replaced by other whites in the normal pattern of residential relocation that occurs in any metropolitan area. Two recent studies of Louisville shed some light on this. In the McConahay and Hawley survey of current Louisville-Jefferson County residents, 16 percent of parents surveyed indicated that, in order to avoid busing, they would not enroll their children in the public schools when they reached school age, whereas only 2 percent expressed a desire to withdraw children who were presently enrolled. ${ }^{58}$ While preferences and behavior in such situations are not highly congruent, it would seem that school nonentrance may be a serious problem. On the other hand, another study of Louisville indicates that residential nonentrance is a small but insignificant factor, at least in countywide school systems. ${ }^{59}$ Although an estimated 312 families moved out of the school system to avoid school desegregation, they were apparently replaced by families with school age children, since the decline in white public

56. Clotfelter, The Detroit Decision and White Flight, 5 J. LeGal. Stud. (1976); Frey, Central City White Flight: Racial and Nonracial Causes (1977) (Institute for Research on Poverty Discussion Paper, Madison, Wisconsin). Moreover, both studies have very poor measures of school desegregation. Clotfelter measures school desegregation as a dummy variable in which any school district in the South was classified as desegregated and any school district in the North was classified as not desegregated. Aside from the wisdom of using a dummy variable (which Frey also uses), there is the problem that in 1970 the South was still highly segregated-about fifteen points above the North. Clotfelter used this same dependent variable in another study. See Clotfelter, School Desegregation "Tipping" and Private School Enrollment, 11 J. Human Resources 28 (1976).

57. Molotch, Racial Change in a Stable Community, 75 AM. J. Soc. 226 (1969); Palmore \& Howe, Residential Integration and Property Values, 10 Soc. Proв. 52 (1962).

58. McConahay \& Hawley, Second Year, supra note 54, at 20-22.

59. Johnson, supra note 54. 
school enrollment in Louisville-Jefferson County can be accounted for by the increase in private school enrollment and the declining birth rate.

\section{B. The Implementation Year Effect of School Desegregation on White Public School Enrollment}

\section{Early Studies Finding No White Flight}

Most of the early national aggregate analyses covering the period from 1967 (or earlier) to 1972 found little or no white flight as a result of school desegregation after controlling for other causes of declining white enrollment. ${ }^{60}$ Farley's study of the largest Northern and Western cities and the fifty largest Southern cities found no significant relationship between white flight and school integration when five year changes in segregation were correlated with the percentage decline in white enrollment over this period. ${ }^{61}$ This method, unfortunately, obscures pre- and post-desegregation enrollment losses, a factor of some importance, since school districts that desegregate tend to have slightly less predesegregation white enrollment decline than those that do not desegregate. Nevertheless, if the desegregation effect is strong it can be detected even using this method.

60. Urban economists suggest the decline in white public school enrollment that began in the 1960 s (long before the advent of school desegregation plans) is in large part a function of the post-World War II suburbanization trend resulting from market forces such as rising incomes and changes in production and transportation, public policies providing subsidies to transportation, highways, and middle income suburban housing; and discrimination against blacks, causing them to be underrepresented in suburbs relative to their economic status. Central city crime and city-suburban fiscal disparities have also been suggested as possible stimulants of this white middle class exodus to the suburbs. In addition, the declining white birth rate has on its own caused a reduction of almost $1 \%$ in overall white school enrollments since 1968 . The yearly decrease is now almost $2 \%$. The black school age population has only recently begun to decline because of a declining birth rate. See U.S. Bureau of the Census, Current Population Reports, Series P-20, No. 294, School Enrollment-Social. and Economic Characteristics of Students, OcTOBER 1975 (1976).

61. Farley, Racial Integration in the Public Schools, 1967-1972: Assessing the Effects of Governmental Policies, 8 Soc. Focus 3 (1975). The "index of dissimilarity" is used to measure the extent of residential or school segregation. When used to measure school segregation, this index takes as its standard the racial composition of a school district, and then compares the racial composition of the individual school to the racial composition of the school district. In each school (i), suppose there are $w_{i}$ whites and $n_{i}$ blacks. The entire school district contains $W$ whites and $N$ blacks. The index of dissimilarity is calculated as follows:

$$
\mathrm{D}=1 / 2 \sum_{\mathrm{i}} \frac{\mathrm{n}_{\mathrm{i}}}{\mathrm{N}}-\frac{\mathrm{w}_{\mathbf{i}}}{\mathrm{W}}
$$

A recently completed analysis of changes in white nonpublic school enrollment between 1960 and 1970 found that in the North there is no relationship between reductions in pupil segregation and increases in white nonpublic school enrollment. There is a relationship for the South, however, although it is rather weak. See Becker, Non-public Schools and Desegregation: Racial Factors and Changes in the Share of Big-City White Pupil Enrollment Going to Non-public Schools (March 1978) (paper presented at the annual meeting of the American Educational Research Association, Toronto, Canada). 
Two other studies-one an analysis of ninety California school districts from 1967 to $1973^{62}$ and the other of eighty-six Northern schools districts from 1964 to $1972^{63}$-also found no white flight, primarily because they analyzed Northern school districts during a time period when, on the whole, there were little or no white reassignments to black schools.

A reanalysis of Coleman's early white flight study, which used data from 1967 to 1972, found no relationship between school desegregation and white flight when the entire sample was analyzed at once and other controls, such as change in black population, density, and per pupil expenditures, were applied. ${ }^{64}$ This study suggests that the reason Coleman found the white flight effect that he did is because he divided his sample into large and small school districts. There was no overall statistically significant desegregation effect during this time period.

In addition to these national aggregate analyses, there are several regional case studies or comparative case studies that also found little or no white flight. ${ }^{65}$ The most widely cited of these is the Giles, Gatlin, and Cataldo study of seven Florida school districts. ${ }^{66}$ There are, however, two problems that limit the usefulness of this study in estimating the extent of white flight attributable to school desegregation. First, because it is a study of seven countywide school districts in Florida desegregated between 1969 and 1971, it does not fit the typical Northern or Southern experience where the central city school district desegregates while the surrounding suburbs remain segregated. Second, and most important, it is not a study of the effect on white enrollment of implementing a desegregation plan. By classifying as "rejectors" those parents whose children were enrolled in public schools in 1971-72, but not in 1972-73, they failed to analyze the implementation year effect since all seven

62. Mercer \& Scout, The Relationship Between School Desegregation and Changes in the Racial Composition of California School Districts, 1966-73 (1974) (unpublished paper, University of California, Riverside).

63. Rossell, School Desegregation and White Flight, 90 Political Sci. Q. 675 (1975). Both the Rossell and the Mercer \& Stout studies use the change in proportion white as their dependent variable. Other studies using change in proportion white as the dependent variable are Levine \& Meyer, Desegregation and White Enrollment Decline in a Big City School District, in THE FutuRE OF BIG Ciтy Schools 55 (1977); Wegman, Desegregation and Resegregation: A Review of the Research on White Flight from Urban Areas, in The Future of Big City Schools 11 (1977) [hereinafter cited as Wegman]; Wegman, Neighborhoods and Schools in Racial Transition, Growth \& Change, July 1975 , at 3 .

64. Jackson, Reanalysis of Colemen's Recent Trends in School Integration, Educ. Researcher, Nov. 1975 [hereinafter cited as Jackson]. See also Coleman, Coleman on Jackson on Coleman, EDuc. RESEARCHER, Feb. 1976, at 3.

65. See Bosco \& Robin, White Flight from Court-Ordered Busing?, 9 URB. Educ. 87 (1974). There are also two case studies which did find significant white flight. See Munford, White Flight from Desegregation in Mississippi, InTegrated Educ., May-June 1973, at 12; Mendro \& Webster, Induced Desegregation: Two Areas of Impact, Student Achievement and Population Resegregation (1975) (unpublished report of the Dallas Independent School District, Dallas, Texas).

66. Giles, Gatlin, \& Catalo, supra note 22. They have also published numerous articles analyzing selected issues from this report. 
of the school districts studied had desegregated in 1971 or earlier. Indeed, in the case of five out of seven school districts, not even the second year effect, but only the third or fourth year effect was analyzed. The significance of this is twofold. First, by analyzing only postimplementation years, the amount of white flight that may have occurred is seriously underestimated, since the effect is greatest in the implementation year. Second, the relationship between racism and white rejection may be seriously underestimated. Parents who decide to try school desegregation for a year or two and then end up withdrawing their children may have substantially different reasons for doing so (for example, failure of a child to adjust, grade problems, problems with transportation) from those of a parent who rejects desegregation outright. Despite these limitations, it should be noted that this study is probably one of the most useful analyses of the characteristics of desegregation plans that cause variations in the degree to which whites reject desegregation during the postimplementation period.

\section{Early Studies Finding White Flight}

Perhaps the most publicized study finding white flight during the same time period as the studies cited above (no later than fall 1972) is that of James S. Coleman and his associates. ${ }^{67}$ There are two Coleman white flight studies; most of the criticisms of Coleman's white flight analysis are based on the earlier study. ${ }^{68}$ This study, presented at the American Educational Association Meetings in April 1975, analyzed the effect of change in segregation from fall 1968 to fall 1969 on white enrollment change from fall 1970 to fall 1972. This time lag method is inappropriate for analyzing this phenomenon, since most school desegregation occurred in the later period rather than in the earlier period, and the effects of present and future desegregation are thus confused. In addition, the sample was divided into the largest twenty-one school districts and the next forty-six school districts. If Coleman had analyzed the two samples together, as virtually every other researcher has done, no doubt he would have found the same statistically insignificant relationship as did the reanalysis of his data. ${ }^{69}$

67. Coleman, Kelly, \& Moore, Recent Trends in School Integration (April 2, 1975) (paper presented at the annual meeting of the American Educational Research Association) [hereinafter cited as Coleman, Integration].

68. Some of the numerous critiques of Coleman's analysis include Jackson, supra note 64; Pettigrew \& Green, School Desegregation in Large Cities: A Critique of the Coleman "White Flight" Thesis, 46 Harv. Educ. Rev. 1 (1976); Robin \& Bosco. Coleman's Desegregation Research and Policy Recommendations, 84 SCHOol Rev. 352 (1976); Weinberg, A Critique of Coleman, InTEGRated Educ., Sept.-Oct. 1975, at 3; Reinhold, Coleman Concedes Views Exceeded His Race Data, N.Y. Times, July 11, 1975, at 1, col. 3; Wisenbaker, A Critique of Trends in School Segregation, 1968-73 (Dec. 1975) (unpublished paper, Michigan State University). The Pettigrew and Green critique does use data from the later Coleman study.

69. Jackson, note 64 supra. 
Thus, despite the fact that virtually all of the early studies, including Coleman's, were flawed in methodology or in the variable measured, there is a much higher level of agreement in findings among those that use the same time period and the same sample, regardless of methodology or variable measurement, than their conclusions suggest.

\section{Later Studies Finding White Flight}

The later Coleman study ${ }^{\mathbf{7 0}}$ is quite different from the earlier one. One additional year's data was added, to cover the period from 1968 through fall 1973, thus snaring Memphis's desegregation with the largest white loss in the United States, and a different method of analysis was employed. In the later study, a pooled yearly cross-sectional change analysis was used to analyze the effect of desegregation on white enrollment change in the same year. The analysis indicates that a substantial desegregation plan results in a doubling of the normal proportional white enrollment loss (an additional 6 percent) in the year of implementation. ${ }^{71}$

All of the later studies by the same researchers discussed above have concluded that school desegregation does indeed accelerate white flight in the year of implementation. Farley's study of the 100 largest metropolitan areas through fall $1974^{72}$ suggests that most cities will have a doubling of their normal white loss rate with a reduction of twenty points in their index of dissimilarity. ${ }^{73}$

The Clotfelter study, ${ }^{74}$ reanalyzing Coleman's data, using the same pooled yearly cross-sectional change analysis, found that an increase in the proportion of black students in the average white child's school in any one year has a strong overall effect on white enrollment in that year if blacks, on the average, make up more than 7 percent of each school's student population. For

70. Coleman, Kelly, \& Moore, Trends in School Segregation, 1968-73 (1975) (Urban Institute Working Paper 722-03-01) [hereinafter cited as Coleman, Trends in School Segregation]. Indeed, virtually all of the second updated studies done by other researchers showed marked improvement in design over their earlier studies. This suggests that practice makes perfect even for presumably well-trained social scientists.

71. Id. at 65. A substantial desegregation plan is one with a -.20 reduction in segregation. A reduction of 20 in Coleman's index $\left(r_{w \cdot b}\right)$ is comparable to a reduction of 20 percentage points in the index of dissimilarity. This estimate of an additional loss of $6 \%$ is for school districts that are $25 \%$ black, with a between-district segregation of 2 .

72. Farley, Can Governmental Policies Integrate Public Schools? (Sept. 1976) (paper presented at the annual meeting of the American Sociological Association, New York) [hereinafter cited as Farley]. Other studies substantiate this general finding. See Armor, White Flight, Demographic Transition, and the Future of School Desegregation (Aug. 1978) (paper presented at the American Sociological Association Meetings, San Francisco, California) [hereinafter cited as Armor, Desegregation]; Roberts, Declining White Enrollments and Desegregation in Central City Public Schools: Their Immediate and Long Term Relationship (March 1978) (a senior thesis submitted to the Harvard University Department of Economics).

73. For a definition of index of dissimilarity, see note 61 supra. As Table 1 indicates, the average court-ordered or $\mathrm{HEW}$-ordered plan reduces segregation by 26 points.

74. Clotfelter, Urban School Desegregation and Declines in White Enrollment: A Reexamination (1977) (unpublished paper, College Park, Maryland) [hereinafter cited as Clotfelter]. 
districts less than 7 percent black, change in interracial exposure has no significant effect on white enrollment. ${ }^{75}$

A study of the impact of school desegregation reassignments on white enrollment in 113 school districts through fall 1975 was undertaken using a methodology that permits analysis of effects peculiar to the periods before, during, and after desegregation. ${ }^{76}$ The variation in school desegregation in the sample of 113 school districts used in the study is given in Table 1. The median year of implementation for the Northern court-ordered plans involving white reassignments is 1973 , and for the Northern HEW plans, 1972. The Southern school districts, which desegregated earlier, have a median year of 1970. These data indicate considerable variation in the amount of school desegregation that occurs in the year of implementation in any one school district, whether one looks at student reassignments, the reduction in segregation, or the resulting level of segregation. Indeed, the last two columns in Table 1 indicate that the variance in allowable segregation is extraordinary even in school districts under court order. ${ }^{77}$

75. Clotfelter's finding that whites are more sensitive to change in the proportion black in their school than they are to desegregation per se (i.e., if there are few blacks in a school system. even massive desegregation will have no effect) is not apparent when such standardized measures as the index of dissimilarity, used by Farley, supra note 61 , or the proportion black in the average white child's school $\left(\mathbf{r}_{\mathrm{wb}}\right)$ used by Coleman, supra note 70 , are used to measure change resulting from school desegregation. Using these standardized measures, School District $A$, with $60 \%$ black students in every school, is given the same score as School District B, with 20\% black students in every school. Thus, these measures indicate nothing about the proportion of blacks and whites in a school other than that it approximates the racial composition of the district, whatever that may be. If, on the other hand, an unstandardized index is used, School District A would have a different score than School District B, reflecting the higher proportion of blacks in each school. The unstandardized index, however, suffers from simultaneity bias when it is used to analyze white flight. That is. as whites leave a school, the proportion of black students goes up and the cause is confused with the effect. Clotfelter has developed a method for eliminating some of this bias. The equation for $s_{w^{\prime} b}$, used by Coleman, is as follows:

$$
s_{w b}=\frac{\sum_{k} n_{k b} P_{k w}}{\sum_{k} n_{k w}}
$$

See Coleman, Trends in School Segregation, supra note 70, at $8 \mathrm{n.4}$. This is the sum of the number of blacks in each school multiplied by the proportion white in the same school. The sum of this calculation for all schools is divided by the total number of whites in the school system. Clotfelter has weighted the measure by an estimate of white enrollment if there had been no white enrollment decline. This can be shown as

$$
\mathrm{S}_{\mathrm{wb}} *=\frac{1}{\mathrm{w}} \sum_{\mathrm{i}} \mathrm{W}_{\mathrm{i}} \frac{\mathrm{B}_{\mathrm{i}}}{\mathrm{h}\left(\mathrm{NW} \mathrm{W}_{1}+\mathrm{W}_{\mathrm{i}}\right)}=\frac{1}{\mathrm{~h}} \mathrm{~S}_{\mathrm{w} \cdot \mathrm{b}}
$$

where $h=\left(N W+W^{*}\right) /(N W+W)$ and $W^{*}$ is white enrollment the previous year, $W$ is white enrollment the year being analyzed, NW is nonwhite enrollment the year being analyzed. However, it should be noted that results virtually identical to Clotfelter's can be obtained by calculating the interaction effect between a standardized measure of desegregation and proportion black. See Farley, supra note 72; Coleman, Segregation, supra note 70; Rossell, Unintended Impacts, supra note 21.

76. Rossell, Unintended Impacts, supra note 21. The study used a quasi-experimental interrupted time series design, requiring that the median year of implementation be identified. See note 24 supra defining quasi-experimental study.

77. This random probability sample stratified by size represents $84 \%$ of all cities over 
[Vol. 42: No. 3

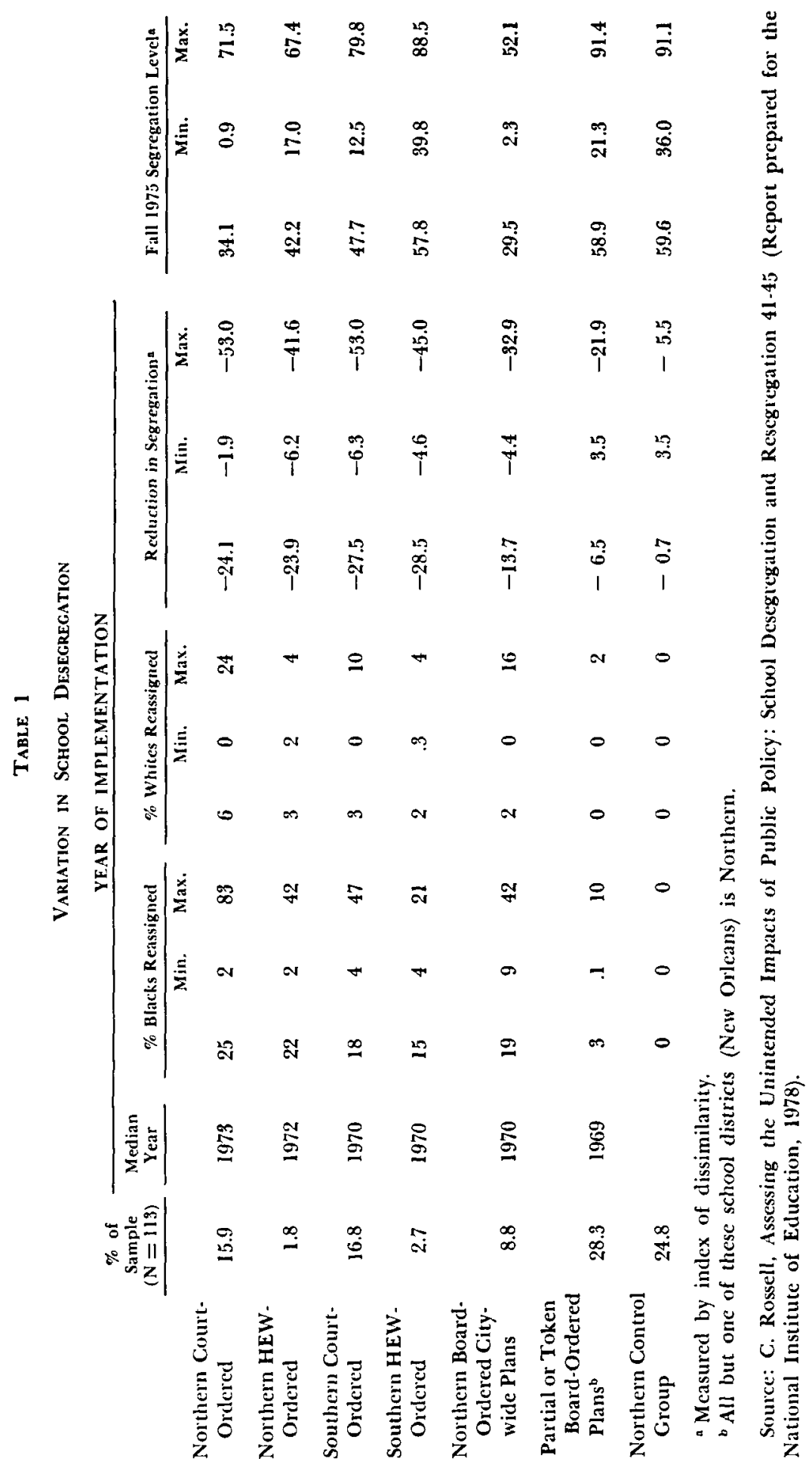


The average additional proportional white enrollment losses associated with different desegregation reassignments in city and metropolitan or large county school districts above and below 35 percent black are given in Table $2 .{ }^{78}$ As this table shows, school desegregation will result in white enrollment losses in the year of implementation that can be as high as an additional 14 percentage points. For example, if the school district begins with a loss rate of -0.2

TABLE 2

Adpitional Percent White Enrollment Change Associated with the IMPLEMENTATION OF DESEGREGATION

\begin{tabular}{|c|c|c|c|c|c|}
\hline \multirow[b]{3}{*}{$\%$ Reassigned } & \multirow[b]{3}{*}{$\triangle$ Segregation } & \multicolumn{4}{|c|}{ CUMULATIVE } \\
\hline & & \multicolumn{2}{|c|}{$<35 \%$ Black } & \multicolumn{2}{|c|}{$\geq 35 \%$ Black } \\
\hline & & City & $\begin{array}{l}\text { Large } \\
\text { County } \\
\end{array}$ & City & $\begin{array}{l}\text { Large } \\
\text { County }\end{array}$ \\
\hline \multicolumn{6}{|l|}{ Blacks Only } \\
\hline $\begin{array}{r}5 \\
20 \\
40\end{array}$ & $\begin{array}{l}-7.7 \\
-18.8 \\
-33.6\end{array}$ & $\begin{array}{l}-0.9 \\
-2.0 \\
-3.4\end{array}$ & $\begin{array}{l}-0.2 \\
-0.3 \\
-0.4\end{array}$ & $\begin{array}{l}-4.0 \\
-5.4 \\
-6.1\end{array}$ & $\begin{array}{l}-3.9 \\
-5.3 \\
-6.0\end{array}$ \\
\hline \multicolumn{6}{|l|}{ Whites Only } \\
\hline $\begin{array}{r}5 \\
20 \\
40\end{array}$ & $\begin{array}{l}-7.8 \\
-19.1 \\
-34.2\end{array}$ & $\begin{array}{l}-3.0 \\
-4.7 \\
-6.3\end{array}$ & $\begin{array}{l}-1.3 \\
-2.1 \\
-3.3\end{array}$ & $\begin{array}{l}-6.6 \\
-9.6 \\
-11.9\end{array}$ & $\begin{array}{l}-6.0 \\
-8.1 \\
-8.9\end{array}$ \\
\hline \multicolumn{6}{|c|}{ Black/White Reassigned } \\
\hline $\begin{array}{l}10 / 5 \\
30 / 5 \\
50 / 15 \\
60 / 25\end{array}$ & $\begin{array}{l}-15.2 \\
-30.0 \\
-52.4 \\
-67.3\end{array}$ & $\begin{array}{l}-3.9 \\
-5.3 \\
-8.0 \\
-8.9\end{array}$ & $\begin{array}{l}-1.6 \\
-1.7 \\
-2.4 \\
-2.7\end{array}$ & $\begin{array}{l}-7.5 \\
-8.2 \\
-12.2 \\
-14.1\end{array}$ & $\begin{array}{l}-6.3 \\
-6.4 \\
-8.1 \\
-8.8\end{array}$ \\
\hline
\end{tabular}

Index of dissimilarity

Source: C. Rossell, Assessing the Unintended Impacts of Public Polficy: School Desegregation and Resegregation (Report prepared for the National Institute of Education, 1978).

$250,000,46 \%$ of all cities from 100,000 to 249,999 , and $8 \%$ of all cities from 50,000 to 99,999 . The level of segregation is measured with the index of dissimilarity. The formula is shown in note 61 supra. The computational formula involves adding up the whites in each school at or above the proportion black in the whole district, adding up the blacks in the same schools, dividing each sum by their respective school district populations, subtracting these sums from each other, and multiplying the absolute value by 100 . The resulting number ranges from 0 to 100 with 0 being perfect racial balance and 100 being perfect segregation.

78. These additional white enrollment losses are calculated from an equation that includes as controls the proportion black in the student population, whether a school district is a Southern city district (e.g., not countywide), the crime rate, and the unemployment rate. The latter two variables are set at the mean for the purposes of calculating losses. The measures of desegregation are the proportion of black students reassigned to white schools, the proportion of whites reassigned to black schools, an interaction effect between the proportion of whites reassigned to black schools and the proportion black, and the ratio of the school district segregation to the SMSA segregation (using the index of dissimilarity). See Rossell, Unintended Impacts, supra note 21 . 
percent it will increase to -14.3 percent with the most extensive plan. This estimate will also vary according to certain variables, which are discussed below.

\section{Cause of Variations in Implementation Effect}

Most comparative studies use aggregate measures of change in segregation as their independent variable, providing little or no information as to which features of a desegregation plan can be manipulated in order to minimize negative effects and maximize positive effects. Such characteristics as the source of the integration, the type of reassignments (for example, black reassignment to white schools and white reassignment to black schools) and the phasing in of plans are usually not included in the analysis.

Nevertheless, the aggregate studies have detected a significant effect between percentage black and the extent of desegregation. That is, a school district or school with a large proportion of students who are black will have more white flight with a given desegregation plan than will a school district with a small proportion of students who are black.

My own study ${ }^{79}$ and that of Giles, Gatlin, and Cataldo ${ }^{80}$ indicate that the tipping point theory does not adequately explain the experience under administratively controlled school desegregation, that is, where the central school authorities, either on their own or under court order, reassign students for purposes of desegregation. The tipping point theory originated in studies of residential succession. ${ }^{81}$ There is some confusion in the literature over the difference between school desegregation resulting from residential succession and that resulting from administratively controlled desegregation. ${ }^{82}$ These are two different phenomena: in the former type (the blue-collar, Northern model), blacks begin moving into a neighborhood and the school becomes increasingly black because whites who move out typically will not be replaced by other whites. Thus, the unwilling white family is exposed to two kinds of desegregation-residential desegregation and school desegregation-as a combined economic and social threat. There is no central control of this process; thus it begins to accelerate after reaching a certain proportion black, usually estimated to be 30 percent. Cities typically have few, if any, resources with which to stabilize this process, and rarely do any try. Therefore, the

79. Rossell, Unintended Impacts, supra note 21.

80. Giles, Gatlin, \& Cataldo, supra note 22, at V-11.

81. See M. Meyerson \& E. Banfield, Politics, Planning and the Public Interest (1955); Aldrich, Ecological Succession in Racially Changing Neighborhoods: A Review of the Literature, 10 URB. AfF. Q. 327 (1975); Wolf, The Tipping-Point in Racially Changing Neighborhoods, 29 Aм. INST. Planners J. 217 (1963).

82. See Stinchcombe, McDill, \& Walker, Is There a Racial Tipping Point in Changing Schools?, J. Soc. Issues, Jan. 1969, at 127; Wegman, supra note 63, for studies that analyze school desegregation resulting from ecological succession but do not distinguish it from administratively implemented school desegregation. 
average white parent assumes that once this process of residential succession begins, both the neighborhood and school eventually will become all black. ${ }^{83}$

This is not the case with administratively controlled school desegregation. In this situation, desegregation occurs only in the school, not in the neighborhood. In addition, the white family, although typically still unwilling, at least has a guarantee of racial balance. Indeed, white families living in racially changing neighborhoods often have a reduction in the proportion black in their school because the school is racially balanced in accordance with the citywide proportion, rather than that of the neighborhood.

As a result, studies that have analyzed school desegregation plans find not a tipping point, but a threshold effect. For example, Giles, Cataldo, and Gatlin, found that the rate of white rejection increased when a school became 30 percent black and also when it became 50 percent black, but this rate of rejection did not increase when the school composition was between 30 and 50 percent, or above 50 percent. The rate remains constant regardless of the busing distance ${ }^{84}$ confirming the NAACP's thesis that "it's not the distance, it's the niggers." 85 My 113 school district study found a threshold effect at 35 percent black in the school system as a whole. ${ }^{86}$ This is shown in Table 2 as a greater loss rate for school districts above 35 percent black. The underlying principle remains the same, since in citywide plans the schools to which white students will be reassigned will have roughly the same proportion black as the citywide proportion.

Several studies indicate that white reassignments to black schools cause substantially more white flight than black reassignments to white schools ${ }^{87}$ In my 113 school district study, almost twice as much white enrollment change occurred with white reassignments to black schools as with black reassignments to white schools. ${ }^{88}$ As Table 2 indicates, and as other studies substantiate, if there are no white reassignments and a school district is less than 35 percent black, black reassignments to white schools result in little or no white flight from the receiving school.

83. This process of ecological succession does not go on in all types of integrated neighborhoods. Notable exceptions are those neighborhoods such as Hyde Park in Chicago, Capitol Hill in Washington, D.C., and the South End of Boston where middle class whites move into a predominantly black neighborhood. Nevertheless, my own observation is that such neighborhoods are also unstable, but in the reverse direction from white working class neighborhoods. That is to say, blocks will often go all white before anyone realizes what happened. This is because the rents and housing prices begin to go up and the blacks that move out are not replaced by other blacks.

84. Giles, Cataldo, \& Gatlin, White Flight and Percent Black: The Tipping Point Re-examined, 56 Soc. Sc. Q. 85 (1975).

85. NAACP Legal Defense and Educational Fund, It's Not the Distance, "It's the Niggers": Comments on the Controversy Over School Busing (May 1972).

86. Rossell, Unintended Impacts, supra note 21 .

87. Giles, supra note 21; Giles, Gatlin, \& Cataldo, supra note 22 at V-11. Lord, supra note 21; Pride \& Woodward, supra note 21; Rossell, Unintended Impacts, supra note 21.

88. Rossell. Unintended Impacts, supra note 21. 
Phasing in of plans may also cause greater white flight than simply implementing a plan in its entirety in the first year. ${ }^{89}$ Phased-in plans typically publicize the desegregation intended for the next stages, thus alerting parents to their child's impending reassignment. This gives parents more time to locate alternative schooling, housing, or jobs outside the central city district and increases their chances of successfully doing so.

The evidence is inconclusive as to whether Southern city school districts have greater white enrollment decline than Northern school districts with the same desegregation plan. Coleman found such an effect, ${ }^{90}$ but Clotfelter, in analyzing Coleman's data, did not. ${ }^{91}$

Several studies have assumed that court-ordered desegregation, all other things being equal, leads to greater white flight than board-ordered plans. ${ }^{92}$ There is simply no evidence to substantiate this claim. Because the proportion of students reassigned-particularly white students-is much greater in court-ordered plans than in board-ordered plans, the white flight resulting from these two types of plans cannot be compared.93 Berkeley, the only school district in my study of 113 city school districts with a board-ordered plan that reassigned a significant proportion of white students to black schools on a mandatory basis, actually had a greater proportional white loss than Pasadena, the most extensive court-ordered plan in the 113-district sample. ${ }^{94}$ This suggests that the characteristics of the plan-for example, whether there is parental choice regarding reassignments-are much more important than the source of the order. There are two reasons why this makes sense. First, even in a board-ordered mandatory plan there is likely to be a large segment of the population that is opposed. ${ }^{95}$ These dissatisfied residents will constitute a potential source of significant white flight even if they are only a small

89. Id. This is a tentative finding, since there are some statistical problems involved in estimating this effect.

90. Coleman, Trends in School Segregation, supra note 70, at 59.

91. Clotfelter, supra note 74. It might make a difference that Clotfelter used Swb*, the weighted unstandardized index, whereas Coleman used Rwb, the standardized index, as the desegregation measure.

92. Coleman, Integration, supra note 67; Coleman, Trends in School Segregation, supra note 70; Armor, Desegregation, supra note 72; Armor, Sociology and School Busing Policy (Sept. 1976) (paper presented at the annual meeting of the American Sociological Association, New York).

93. Terms such as mandatory and voluntary desegregation are often confused with courtordered and board-ordered desegregation. The terms mandatory and voluntary refer to the degree of parental choice, whereas the terms court-ordered and board-ordered refer to the source of the order to desegregate. Court-ordered plans can be either mandatory (as in Boston and Pasadena) or voluntary (as in Milwaukee, Houston, and San Diego). In the latter plans, the courts have ruled that the school districts have fulfilled their constitutional obligations by implementing a voluntary busing plan, although such plans rarely result in more than a ten point reduction in segregation. Board-ordered plans can also be mandatory (as in Berkeley and Evanston) or voluntary. The latter are typically called majority to minority transfer programs.

94. Rossell, Unintended Impacts, supra note 21.

95. An unsuccessful school board recall election was held in Berkeley. 
portion of the population. Second, support for school desegregation (which would be expected in middle-class communities with board-ordered plans) is not reliably related to white flight behavior. ${ }^{96}$

Evidence that there is greater white flight with elementary school desegregation than with secondary school desegregation is found in two case studies, one of Denver ${ }^{97}$ and the other of Boston. ${ }^{98}$ In order to determine whether differential changes in white loss between grade levels could be the result of grade reorganization within schools, projected and actual enrollments must be analyzed. No comparative study has done this adequately. ${ }^{99}$

The Denver case study indicates that in this school district there was significantly greater white flight from elementary schools than from junior and senior high schools. The Boston case study also indicates greater white flight from elementary schools than from junior and senior high schools, although the difference is not significant.

Income and, to a lesser degree, education are related to white flight. There is some evidence to suggest that those individuals who do leave in response to school desegregation tend to be of higher income or educational level, or both, than those who stay. ${ }^{100}$

Virtually all studies agree that metropolitan plans, or countywide plans, all other things being equal, will have less white flight in response to school desegregation than city-only plans will. There are two reasons for this. First, because countywide plans incorporate suburban areas, they will have a smaller proportion of students who are black in their school system than do most city school disricts. Second, there will be little opportunity for residential relocation to a more segregated school district. This opportunity is typically measured in the aggregate analyses as the ratio of the school district's segregation level to the metropolitan area's segregation level. The more segregated the metropolitan area is relative to the school district, the greater the decline in white enrollment in that school district; ${ }^{101}$ but if the entire metropolitan area

96. See McConahay \& Hawley, Preliminary Results, supra note 27; Giles, Gatlin, \& Cataldo, supra note 22 , at IV-13.

97. Rossell, Unintended Impacts, supra note 21 , at appendix 1.

98. Massachusetts Research Center, Education and Enrollments: Boston During Phase II 20 (report, 1976).

99. Coleman decided to ignore this problem and selected all schools having a 6 th grade as elementary and all schools having a l0th grade as secondary. His conclusion was that white loss as a result of school desegregation was greater at the elementary school level than at the high school level. He later decided that this was incorrect and changed the procedure so that any school that included a grade 9, 10,11, or 12 would be considered secondary and all others considered elementary. Preliminary analysis showed almost equal losses from high school and elementary school. See Coleman, Trends in Segregation, supra note 70, at 77-78.

100. Giles, Gatlin, \& Cataldo, supra note 22 at IV-3; Lord, supra note 21; Pride \& Woodward, supra note 21.

101. See Coleman, Trends in Segregation, supra note 70; Farley, supra note 72; Rossell, Unintended Impacts, supra note 21. 
is desegregated, there will be no difference in segregation between the school district and surrounding districts.

Although this appears to contradict one of the Boston studies, ${ }^{102}$ there are two possible explanations. First, there could still be an increase in white outmigration in the year of implementation, even though it is unrelated to opposition to the desegregation plan. Second, it is also conceivable that the school district/metropolitan area segregation ratio is masking some other characteristics of central city school districts besides accessibility to white suburbs. For example, central city school districts usually have a large number of parochial schools that can serve as a haven for white students fleeing desegregation, meaning that students may be leaving the public schools but not the city. ${ }^{103}$

Several studies indicate that such nonracial characteristics of the receiving school as the quality of the physical plant and the average reading scores have no relationship to white flight. ${ }^{104}$ Perhaps most surprising, given all the furor over the issue, busing distance has no relationship to white flight, once the proportion black in the receiving school is controlled. ${ }^{105}$ Although an increase in busing distance produces some resistance, if children must be bused, most white parents would prefer that their children have a long bus ride to a school in a white neighborhood than a shorter ride to a school in a black neighborhood. ${ }^{106}$

Few studies have examined systematically the effect of such variables as protest and leadership statements on white flight, primarily because the costs of collecting such data are quite high. Even the Giles, Gatlin, and Cataldo study, which has data on protest activity, does not try to link it to the extent of white flight, although the study notes that protestors were no more likely to reject (withdraw their children from the public schools) than were those who did not protest. ${ }^{107}$ One ten-city study found that leadership statements had no effect on white flight when the extent of school desegregation and the degree of protest were controlled. ${ }^{108}$ This effect may be attributable to the fact that there were very few leadership statements one way or. the other, and even fewer in support of school desegregation. ${ }^{109}$ Newspaper coverage of

102. Taylor \& Stinchcombe, supra note 26.

103. The strength of the coefficient for the metropolitan segregation variable may lead researchers to conclude that students are leaving the city when they are only leaving the public schools.

104. Pride \& Woodward, supra note 21. However, the Massachusetts Research Center report, supra note 98 at 47.51 , found that a school's age, per pupil expenditures, and pupil-teacher ratios affected whether the school attained its projected enrollment.

105. Giles, Gatlin, \& Cataldo, supra note 22; Pride \& Woodward, supra note 21.

106. One study, however, suggests that staggered school starting times in order to minimize busing costs will result in greater white flight. Pride \& Woodward, supra note 21.

107. Giles, Gatlin, \& Cataldo, supra note 22, at III-4.

108. Rossell, Public Behavior, supra note 33, at 133-34.

109. See discussion supra at note 37 and accompanying text. 
school desegregation did have a significant effect on white flight, however, even when the extent of school desegregation reassignments, the proportion black, and the level of protest were controlled. The more negative the coverage of desegregation during the predesegregation school year, the greater the white flight. ${ }^{10}$ This was also true of protest demonstrations during the first six months of the school year before the desegregation plan is to be implemented. ${ }^{11}$ Protest can increase white flight by symbolically illustrating the perceived costs of school desegregation.

\section{The Long Term Effect}

Most of the studies of the effect of school desegregation on white flight have failed to consider the time dimension. To measure the long term effect of desegregation on white flight, a quasi-experimental design should be employed. ${ }^{12}$ Only two studies have done so. ${ }^{113}$ Four other studies that have employed a different approach also have produced some useful information on the long term impact of desegregation. ${ }^{114}$

Analysis of the long term effect in a sample of 113 school districts ${ }^{115}$ indicates that the implementation year effect is offset in postimplementation years by less than normal white enrollment losses. This is especially pronounced in the fourth year after implementation of the desegregation plan $(T+4)$, that is, the fifth year of desegregation. The effect of the extent of school desegregation, measured as (1) the proportion of whites reassigned to black schools, (2) the proportion of blacks reassigned to white schools, or (3) the reduction in segregation over time is shown in Table 3 . There is a small, but negligible, anticipation effect in the year immediately preceding the implementation year $(T-1) .{ }^{16}$ Secondly, the effect of desegregation on white enrollment is negative only in the year of implementation and the first postdesegregation year. ${ }^{117}$ There is a positive relationship between the extent of desegregation in the year the plan is implemented $(T+0)$ and changes in white enrollment by the end of the second year of the plan $(T+2)$. In other words, the

110. Rossell, Public Behavior, supra note 33 at 134.

111. Id.

112. See note 24 supra.

113. Armor, Desegregation, supra note 72; Rossell, Unintended Impacts, supra ntoe 21.

114. Johnson, supra note 54; McConahay \& Hawley, Preliminary Results, supra note 27; Roberts, Declining White Enrollments and Desegregation in Central City Public Schools. supra note 72; Coleman, Trends in Segregation, supra note 70.

115. Rossell, Unintended Impacts, supra note 21, at 26-31.

116. This is not significantly different from zero at the aggregate level, although for individual cases it may be quite large. When reassignments in $T-1$ are controlled for, the anticipation effect is even smaller-close to zero. Nevertheless, if such an effect is spread out over a few years because of prolonged litigation, then there is no way to detect it using this type of analysis.

117. Even in the first postimplementation year, the correlation between decline in white enrollment and the extent of desegregation is significantly less than that found in the year in which the plan is implemented. 
TABLE 3

Partial Correlation Between School Desegegation T+0* and \% Change IN White ENROLLMENT

\begin{tabular}{lrrrrrrrr} 
& \multicolumn{7}{c}{ Percent Change in White Enrollment } \\
\cline { 2 - 10 } $\log _{10} \%$ Whites Reassigned $\mathrm{T}+0$ & \multicolumn{1}{c}{$\mathrm{T}-2$} & $\mathrm{~T}-1$ & $\mathrm{~T}+0$ & $\mathrm{~T}+1$ & $\mathrm{~T}+2$ & $\mathrm{~T}+3$ & $\mathrm{~T}+4$ & $\mathrm{~T}+5$ \\
\cline { 2 - 10 } $\log _{10} \%$ Blacks Reassigned $\mathrm{T}+0$ & .16 & -.04 & -.51 & -.07 & .20 & .16 & .23 & .40 \\
$\Delta$ Segregation $^{2} \mathrm{~T}+0$ & -.24 & -.06 & .44 & -.06 & -.19 & -.15 & -.25 & -.51 \\
df & 93 & 103 & 105 & 105 & 101 & 90 & 73 & 36
\end{tabular}

* $T=$ year; $T+0=$ year in which the major school desegregation plan is implemented.

andex of dissimilarity

Source: C. Rossell, Assessing the Unintended Impacts of Public Policy: School Desegregation and Resegregation 28 (Report prepared for the National Institute of Education, 1978).

greater the amount of desegregation when the plan is initially implemented, the smaller the decline in white enrollment two years later.

Coleman also found the same positive effect in postimplementation years, although it was attributed to unspecified statistical problems. ${ }^{118}$ This finding is also corroborated, however, by a recent analysis of fifty-eight school districts. ${ }^{19}$ The study found that if desegregation reassignments were 10 percent of the enrollment (moderate desegregation), the district would lose an additional 4.2 percent of its white enrollment in the short run, but gain an additional 3.1 percent in the long run. If a district reassigned 20 percent of its students (the average desegregation plan), a marginal short run loss of 8.5 percent and a marginal long run gain of 6.1 percent is predicted. A desegregation plan in which 30 percent of the total student enrollment was reassigned would cause a short run loss of 12.7 percent and a long run gain of 9.2 percent. This analysis probably overestimates the long run gain because no distinction was made between black and white reassignments. As noted earlier, the effect of black reassignments is quite different from the effect of white reassignments on white flight, and more whites are reassigned in the average plan in later years.

The McConahay and Hawley survey of Louisville-Jefferson County ${ }^{120}$ indicates a dramatic decline in the proportion of white children who will be withdrawn from the public schools in the second and third years of the plan. The number withdrawn in the year of implementation is estimated to be between 10 and 15 percent; the proportion who will be withdrawn at the end of

118. Coleman, Trends in Segregation, supra note 70, at 67.

119. Roberts, supra note 72.

120. McConahay \& Hawley, Second Year, supra note 54, at 21. 
the first year because of busing is less than 2 percent. ${ }^{121}$ By the end of the second year, 1976-77, the proportion of parents saying that they would withdraw their children from the public schools because of busing was down to less than 1 percent. This indicates almost no effect, given the divergence between intent and action.

Nevertheless, there may be some additional long term impact resulting from nonentrance. One type of nonentrance is the failure of residents to enroll their children in the public schools when they reach school age. Almost 16 percent of parents in Louisville-Jefferson County with children too young to attend school indicated at the end of the first year of implementation of the desegregation plan that they did not intend to send their children to the public schools because of busing. Assuming these children are evenly distributed over the five preschool years and that there is a divergence between intent and action, then each year about 1 to 2 percent of the eligible white children will not be enrolled when they reach school age. ${ }^{122}$ The study does not, however, provide information on the differential neighborhood effect; the nonentrance impact in some neighborhoods may be offset by less than normal losses in other neighborhoods.

The Armor study of twenty-three court-ordered districts is the only study to conclude that school desegregation does have a long term negative impact on white enrollment. ${ }^{123}$ The study estimates that at the end of the fourth year of desegregation, school districts that have desegregated under court order will still have a loss rate that is twice their normal rate. Armor uses a technique of estimating projected white enrollment with annual birth rates adjusted to reflect both survival and net out-migration. There are problems, however, with using 1970,1960 , and 1950 census data to predict future annual changes a decade later. The initial projections (that is, the change in white enrollment in the first year of the desegregation plan), on which the changes in white enrollment in subsequent years are based, are different enough from the actual change in white enrollment to account for most of the difference between actual and projected white enrollment change in postimplementation years. ${ }^{124}$

If implementation year losses are followed by less than normal losses, as most of the studies show, then school districts eventually should make up

121. This undoubtedly exaggerates the proportion of parents who actually will withdraw their children from the public schools since the decision to do so is also a function of the options available.

122. There was very little difference in this proportion when the same question was asked a year later. Id. at 27-28.

123. Armor, Desegregation, supra note 73.

124. In addition, Armor's projected normal loss rates, assuming no desegregation, are about half those of the control group districts (those not undergoing desegregation) in my study which had the same proportion minority students. Rossell, Unintended Impacts, supra note 21. 
their initial loss. The net losses, depending on the proportion black or white assigned and the reduction in segregation, for my 113-school district study are shown in Table $4 .^{125}$ By the fourth year of the plan $(T+4)$ there is a net gain in white enrollment in those school districts where only black.students were reassigned for purposes of desegregation. The average court-ordered two-way busing plan ( 30 percent blacks and 5 percent whites reassigned) still results in a net gain in all but those city school districts where the black student enrollment is 35 percent of the total or greater. Even in these districts, the net loss is negligible at the end of the four-year time period. The most extensive two-way reassignment plan (such as that implemented in Pasadena and Pontiac) has a negligible net loss in those city school districts with less than 35 percent black enrollment, a net gain of almost 7 percentage points in countywide school districts with less than 35 percent black, and a net gain of

TABLE 4

Five Year ( $\mathrm{T}-1$ to $\mathrm{T}+4$ ) Additional Percent White Exrollment Change Associated With Desegregation

\begin{tabular}{|c|c|c|c|c|c|}
\hline \multirow[b]{3}{*}{$\%$ Reassigned } & \multirow[b]{3}{*}{$\Delta$ Segregation ${ }^{\star}$} & \multicolumn{4}{|c|}{ Cumulative } \\
\hline & & \multicolumn{2}{|c|}{$<35 \%$ Black } & \multicolumn{2}{|c|}{$\geq 35 \%$ Black } \\
\hline & & City & $\begin{array}{l}\text { Large } \\
\text { County }\end{array}$ & City & $\begin{array}{l}\text { Large } \\
\text { County }\end{array}$ \\
\hline \multicolumn{6}{|l|}{ Blacks Only } \\
\hline $\begin{array}{r}5 \\
20 \\
40\end{array}$ & $\begin{array}{l}-7.7 \\
-18.8 \\
-33.6\end{array}$ & $\begin{array}{l}+3.3 \\
+3.5 \\
+2.2\end{array}$ & $\begin{array}{l}+4.3 \\
+5.8 \\
+6.5\end{array}$ & $\begin{array}{l}+3.3 \\
+3.5 \\
+2.2\end{array}$ & $\begin{array}{l}+4.3 \\
+5.8 \\
+6.5\end{array}$ \\
\hline \multicolumn{6}{|l|}{ Whites Only } \\
\hline $\begin{array}{r}5 \\
20 \\
40\end{array}$ & $\begin{array}{r}-7.8 \\
-19.1 \\
-34.2\end{array}$ & $\begin{array}{l}-1.3 \\
-2.8 \\
-3.7\end{array}$ & $\begin{array}{l}-.3 \\
-.4 \\
-.5\end{array}$ & $\begin{array}{l}-4.6 \\
-6.6 \\
-8.9\end{array}$ & $\begin{array}{l}-3.7 \\
-5.0 \\
-5.6\end{array}$ \\
\hline \multicolumn{6}{|c|}{ Black/White Reassigned } \\
\hline $\begin{array}{l}10 / 5 \\
30 / 5 \\
50 / 15 \\
60 / 25\end{array}$ & $\begin{array}{l}-15.2 \\
-30.0 \\
-52.4 \\
-67.3\end{array}$ & $\begin{array}{l}+2.8 \\
+2.5 \\
-.3 \\
-.9\end{array}$ & $\begin{array}{l}+4.7 \\
+6.1 \\
+6.3 \\
+6.5\end{array}$ & $\begin{array}{l}-.6 \\
-1.2 \\
-4.6 \\
-5.7\end{array}$ & $\begin{array}{l}+1.3 \\
+2.5 \\
+2.0 \\
+1.8\end{array}$ \\
\hline
\end{tabular}

"Index of dissimilarity

Source: C. Rossell, Assessing the Unintended Impacts of Public Policy: School Desegregation and Rescgregation 35 (Report prepared for the National Institute of Education, 1978).

125. Rossell, Unintended Impacts, supra note 21 . I also tried dividing the school districts into an experimental group, which had implemented extensive two-way busing plans, and a control group (using the median year for the control group) with the same predesegregation proportional white enrollment loss, a similar proportion black the year before implementation, and roughly the same pupil enrollment. At the end of the five-year period, the control group had a proportional white enrollment decline of -5.2 while the desegregated school districts had a proportional white enrollment decline of -3.8 . 
2 percentage points in countywide school districts with a black enrollment higher than 35 percent. It is only in those city school districts with 35 percent black enrollment or more that there is still a net loss-almost 6 percentage points. Nevertheless, a comparison of this figure to the parallel one in Table 2 shows that these school districts have made up more than half of their implementation year loss, at least relative to school districts that have not desegregated.

\section{The Effect of White Flight on Desegregation Outcomes}

There is virtually no evidence on the effect of white flight on educational outcomes in the classroom. Without knowing the impact white flight has on the socioeconomic characteristics of the classroom, no prediction can be made regarding its impact on achievement.

The impact of white flight on the instrumental goal of interracial contact can, however, be measured by using Coleman's unstandardized index of the proportion white in the average black child's school ${ }^{126}$ and examining the relationship of this measure to various school district characteristics including desegregation reassignments.

The evidence, shown in Table 5, indicates that every desegregation plan, even the most extensive, has a net benefit-that is, benefits exceed costs. Paradoxically the net benefit in black interracial contact with whites is greatest in school districts with 35 percent or more black enrollment, despite the fact that when desegregation occurs these school districts undergo the greatest declines in white enrollment. In short, even the most extensive plan is effective in obtaining the instrumental goal of black interracial contact with whites, and this net benefit continues at least as long as four years after implementation of the desegregation plan.

The Coleman study found very much the same thing. ${ }^{127}$ Its equations show that school districts that desegregate have, at the end of a ten-year period after desegregation, a level of interracial contact (proportion white in the average black child's school) that is still twice that of school districts that have not desegregated, despite a greater decline in white enrollment compared to those districts that did not desegregate during that period.

126. This can be calculated as follows:

$$
s_{b w}=\frac{\sum_{k} n_{k n} P_{k w}}{\sum_{k} n_{k b}}
$$

See Coleman, Trends in School Segregation, supra note 70, at 8 . This is the sum of the number of blacks in each school multiplied by the proportion white in the same school. The sum of this calculation for all schools is divided by the total number of blacks in the school system.

127. Id. at 75 . 
TABLE 5

Net Benefit in Black Contact with Whites

(Proportion White in the Average Black Child's School)

\begin{tabular}{|c|c|c|c|}
\hline \multirow[b]{2}{*}{$\%$ Reassigned } & \multirow[b]{2}{*}{ Segregation ${ }^{a}$} & \multicolumn{2}{|c|}{ Cumulative } \\
\hline & & $<35 \%$ Black & $\geq 35 \%$ Black \\
\hline \multicolumn{4}{|l|}{ Blacks Only } \\
\hline $\mathbf{5}$ & -7.7 & +.09 & +.09 \\
\hline 20 & -18.8 & +.12 & +.12 \\
\hline 40 & -33.6 & +.16 & +.16 \\
\hline \multicolumn{4}{|l|}{ Whites Only } \\
\hline 5 & -7.8 & +.03 & +.07 \\
\hline 20 & -19.1 & +.04 & +.10 \\
\hline 40 & -34.2 & +.05 & +.11 \\
\hline \multicolumn{4}{|c|}{ Black/White Reassigned } \\
\hline $10 / 5$ & -15.2 & +.14 & +.18 \\
\hline $30 / 5$ & -30.0 & +.17 & +.21 \\
\hline $50 / 15$ & -52.4 & +.19 & +.24 \\
\hline $60 / 25$ & -67.3 & +.20 & +.25 \\
\hline
\end{tabular}

a Index of dissimilarity

Source: C. Rossell, Assessing the Unintended Impacts of Public Policy: School Desegregation and Resegregation (Report prepared for the National Institute of Education, 1978).

\section{E. Summary}

The research on school desegregation and white flight indicates that the following propositions characterize the phenomenon of white flight:

1. Surveys show little or no increase in residential relocation among families opposed to school desegregation.

2. There is some nonentrance of students from families already residing in the school district because of school desegregation, but it is difficult to estimate the long term impact of this.

3. School desegregation accelerates the "normal" decline in white enrollment in the year of implementation, largely due to enrollment in private schools.

4. At the aggregate level, there is little "anticipation" white flight the year before implementation.

5. The average desegregation plan-about 30 percent black students and 5 percent white students reassigned, with a reduction in segregation of 30 points-results in a little more than a doubling of the normal decline in white enrollment the year of implementation.

6. White reassignments to formerly black schools result in almost twice the implementation year loss of black reassignments to white schools.

7. There is a "threshold effect" when the black enrollment of the school is 30 percent and that of the district, 35 percent. There will be an 
additional loss in white enrollment when school districts have a black enrollment above 35 percent, but this additional loss occurs only in the year of implementation.

8. There is greater white flight when elementary schools are desegregated than when secondary schools are.

9. Phased-in plans may result in greater white flight than plans implemented in one year.

10. Unfavorable newspaper coverage of desegregation during the year before implementation increases white flight.

11. The greater the extent of protest activity during the year before desegregation, the greater the white flight.

12. Those most likely to withdraw their children from the public schools because of school desegregation tend to be of higher income and educational level than those who do not.

13. Metropolitan area plans have less white enrollment loss with desegregation than do city school district plans.

14. A greater than normal implementation year loss because of school desegregation is followed by less than normal postimplementation year losses.

15. In city school districts with less than 35 percent black enrollment, and in countywide school districts, the average two-way desegregation plan has an overall effect on white enrollment at the end of five years that is positive.

16. In city school districts with an enrollment at or above 35 percent black, the average two-way desegregation plan results in a negligible loss, an additional 1.2 percent, at the end of the five year period. The most extensive plan shows an additional 6 percent loss. This is still a substantial reduction of the implementation year loss.

17. All school desegregation plans result in a substantial net benefit in terms of the only measurable school desegregation outcome at the aggregate level-the instrumental goal of interracial contact. Thus the proportion white in the average black child's school increases substantially despite implementation year losses in white enrollment. This effect is greatest in school districts with enrollments at or above 35 percent black, despite the fact that those districts experience the greatest losses in white enrollment.

\section{III}

\section{The Effect of Desegregation on Community Attitudes}

This section of the article describes (1) the findings of national surveys on racial attitudes and opinions, (2) the distribution of attitudes in some desegregated communities, (3) voting behavior in some desegregated communities, 
and (4) the relationship of community attitudes to student attitudes. As noted earlier, the hypothesis that school desegregation might bring about a positive change in attitudes toward racial issues is predicated on two decades of social psychological research, which suggests that when individuals are forced to change their behavior so that behavior is congruent with attitudes, attitudes will change in order to conform to behavior. ${ }^{128}$ A significant component of this theory is that the greatest attitudinal changes will occur when the least force is used. Thus the degree to which attitudes change is likely to depend not only on the characteristics of the individual involved and the nature of the desegregation process, but also on the extent of protest and white flight characterizing the earlier phases of social change.

\section{A. The National Surveys}

National surveys on racial integration attitudes over the last decade have indicated a trend toward increasing acceptance of the principle of integration, despite dire predictions of a backlash against forced desegregation. The National Opinion Research Center at the University of Chicago has conducted national surveys on racial attitudes since 1942. One question periodically repeated in the surveys is whether white and black students should attend school together. In 1942 the proportion of respondents agreeing was 30 percent; in 1956, 48 percent; in 1963, 63 percent; in 1970, 74 percent; in 1972, 86 percent; and in 1976,83 percent. ${ }^{129}$

The reduction in racial intolerance in the North is compared to that in the South in Figure $1 .{ }^{130}$ The greatest reduction in school segregation in the South occurred between 1969 and 1971, followed in 1970-1972 by the largest decrease in racial intolerance. While it cannot be concluded from this that the

128. L. Festinger, supra note 9; J. Brehm and A. Cohen, supra note 9; M. Deutsch \& $M$. Collins, Interracial Housing: A Psychological Evaluation of a Social Experiment (1951); D. Wilner, R. Walkley, \& S. Cook, Human Relations in Interracial housing: A Study of The Contact Hypothesis (1955).

129. Sheatsley, White Attitudes Towards the Negro, 95 DaEdalus 217, 219 (1966) [hereinafter cited as Sheatsley]; Taylor, Sheatsley, \& Greeley, supra note 8, at 42.

130. Data in Figure 1 are from two different studies: Taylor, Sheatsley, \& Greeley, supra note 8; Farley \& Wurdock, Integrating Schools in the Nation's Largest Cities: What Has Been Accomplished and What is Yet to be Done 11 (1977) (unpublished paper, Ann Arbor). To compare the scales used by the two studies, the Treiman scale of racial tolerance is reversed so that it measures racial intolerance, that is, the failure to give a pro-integration response to the five questions used on the scale. The five questions in the Treiman scale are (1) "Do you think white students and Negro students should go to the same schools or to separate schools?" (2) "How strongly would you object if a member of your family wanted to bring a Negro friend home to dinner?" (3) "White people have a right to keep Negroes out of their neighborhoods if they want to and Negroes should respect that right." (4) "Do you think there should be laws against marriages between Negroes and whites?" (5) "Negroes shouldn't push themselves where they're not wanted." See Taylor, Sheatsley, \& Greeley, supra note 8; Treiman, Status Discrepancy and Prejudice, 71 Ам. J. Soc. 651 (1966). 
Figure 1

Reductions in School Segregation and Reouctions in Racial Intolerance

1967-1976

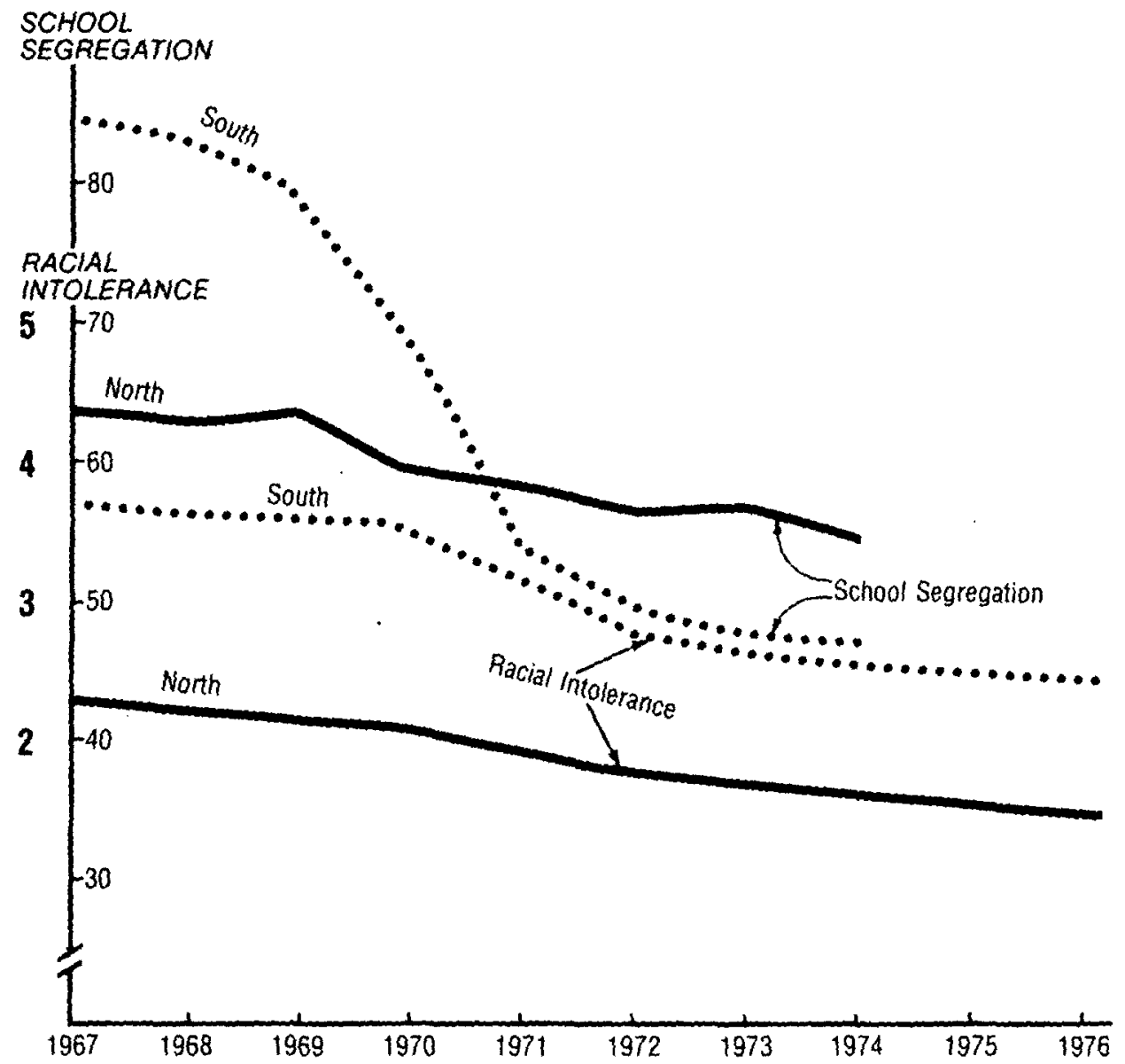

SOURCE: R. Farley \& C. Wurdock, Integrating Schools in the Nation's Largest Cities: What Has Been Accomplished and What Is Yet To Be Done II (Ann Arbor: unpublished paper, 1977); Taylor, Sheatsley, \& Greeley, Periods of Chonge in Ameritan Racial Atcitudes, 238 Scientric AM. (June 1978). 
reduction in segregation had any relationship to the reduction in racial intolerance, it is evident that desegregation failed to produce a backlash. Moreover, the smaller reduction in school segregation in the North and West is paralleled by an almost identically small decrease in racial intolerance.

An analysis of the 1956 and 1963 NORC surveys attempted to distinguish cause and effect by establishing that the areas in the South that were integrated first were not areas where majority opinion was in favor of integration-only 31 percent of whites in these areas were in favor of integrated schools. ${ }^{131}$ By 1963, after substantial desegregation, this figure had increased to 58 percent. At the same time, only 38 percent of whites approved of integrated schools in those Southern communities that had only token desegregation, and only 28 percent in those school systems remaining highly segregated. However, the conclusion that school integration resulted in an increase in pro-integration attitudes must be treated with some caution, since the analysis failed to employ a quasi-experimental panel survey at the school district level.

The NORC surveys also indicate that racial attitudes are stable over time, despite intervening violent confrontations and outbreaks of racial hostility. ${ }^{132}$ What this suggests is that there is little or no backlash with regard to racial goals, although there may be backlash regarding methods and the speed with which these goals are attained. A significant correlation was found between the incidence of racial confrontations (as reported on the front page of the New York Times) and negative responses by whites to the question whether blacks were pushing "too fast." ${ }^{133}$ As the number of racial confrontations increased, the proportion of whites responding "too fast" went from 30 percent in 1962 to over 50 percent in 1966, indicating that, at least at the national level, there is a spectrum of attitudes regarding methods and the pace of achieving integration that is responsive to short term events, even though over the long term, acceptance of the goals involved is increasing.

\section{B. Community Attitudes}

National surveys fail to provide information on variations in attitudes among communities. The most accurate method of determining the effect of school desegregation on the attitudes of those living in a particular community is a quasi-experimental panel survey-periodic observations, over at least a decade, of pre- and post-desegregation attitudes held by the same individuals in that community, as well as of a comparable control group. No such study exists, partly because of the technical problems and the costs involved in employing such a design.

131. Sheatsley, supra note 129 .

132. Id.

133. J. Ross, Resistance to Racial Change in the Urban North, 1962-1968, chapter 2 (1973) (unpublished doctoral dissertation, Harvard University). 
The few available studies, although imperfect, substantiate the findings of the national surveys regarding the absence of a backlash against the principle of school integration. The Taylor and Stinchcombe analysis of Boston found that the same proportion of individuals supported racial integration or school integration, or both, before desegregation as after, despite the extensive protest and violence. ${ }^{134}$ In addition to this study, two others show little difference in support for racial or school integration between those who have their children in public school and those who do not. ${ }^{135}$ These studies are neither quasi-experimental nor panel surveys. Hence, there is no information on what is happening concurrently to attitudes in segregated school districts, and the same respondents are not re-interviewed in the district being studied. As a result, there is no basis for interpreting these trends in attitudes over time. Moreover, all of these studies were conducted in school districts that had considerable protest and violence over school desegregation and significant white flight, meaning that there is no variance to prove the thesis that the characteristics of the first phase of social change will affect the second phase of social change. Nevertheless, there is some useful information that can be obtained from these studies. They indicate, for example, that the importance of the busing problem begins to recede by the second year of implementation. At the end of the first year of desegregation (1975-76) in Louisville-Jefferson County, 70 percent of the respondents cited busing as the most important problem facing the community. By the end of the second year, only 48 percent of the respondents did so. ${ }^{136}$

Although there is a high level of support for the principle of school integration, busing to achieve racial balance or school desegregation is overwhelmingly opposed. ${ }^{137}$ Busing is a symbol that whites almost automatically reject, regardless of how inconsistent this is with other attitudes and even though they may at the same time support specific plans that involve some busing. The Pontiac survey showed that in 1975,84 percent of all white parents preferred that their children attend a school 25 to 50 percent black. This is an increase from the previous year when 78 percent supported this racial mix. Nevertheless, only 13 percent of white parents supported "the desegregation plan using busing." ${ }^{138}$ Even more interesting is the Louisville-Jefferson County survey, which showed that in 1977,50 percent of all whites thought it a "good idea" for "children to go to schools that have about the same propor-

134. Taylor \& Stinchcombe, supra note 26.

135. McConahay \& Hawley, Second Year, supra note 54; Slawski, Pontiac Parents: For Busing or Integration?, 8 EDUC. \& URB. Soc'y 477 (1976) [hereinafter cited as Slawski]. Neither of these studies are quasi-experimental. See also Ross \& Berg, The Social Controversy: A Crisis of Law in Society, supra note 26.

136. McConahay \& Hawley, Second Year, supra note 54, at 3.

137. G. ORFIELD, supra note 18 , at 108-118.

138. Slawski, supra note 133 , at $487,490$. 
tion of blacks and whites as generally exists in the Louisville-Jefferson County area."139 Nevertheless, only 5 percent supported the current busing plan, which does exactly that.

Both blacks and whites in Louisville greatly underestimate the proportion of their neighbors who think racial balance is a good idea. Whereas 50 percent of the respondents thought racial balance was a good idea, only 19 percent believed their neighbors think so. While 80 percent of blacks thought racially balanced schools were a good idea, only 55 percent thought their neighbors did. ${ }^{140}$ A partial explanation for the tremendous opposition to actual busing plans, therefore, may be this false perception of overwhelming community opposition to racial balance.

There is some evidence from the Boston and Louisville studies that parents with school age children who participated in the desegregation plan begin to justify their decision by supporting desegregation to a greater degree than those parents whose children are not yet of school age, even though the latter group is likely to be younger and thus normally more "liberal." The Ross study indicates that whites whose children were bused during Phase I (1974-75) of Boston's desegregation plan were generally more certain black children benefitted from integration and less certain about the negative effects of school desegregation on white children than those with no school age children. ${ }^{141}$ In Louisville, the proportion of parents intending not to enroll their preschool children in the public schools when they reached school age was four times greater for those who had no school age children than for those who already had some children in the public schools. ${ }^{142}$ Nevertheless, despite this evidence supporting the hypothesized attitudinal change, these studies indicate there are strong parental fears about the outcome of school desegregation on academic performance. In Louisville these fears have increased over time. ${ }^{143}$

There also appears to be increasing polarization with regard to important racial issues. For example, among those opposed to busing to achieve racial desegregation (overwhelmingly white), there has been an increase between 1976 and 1977 in the proportion who believe that busing adversely affects the quality of education ( 78 to 81 percent). More disturbingly, there has been a substantial increase (from 38 to 51 percent) in the proportion believing that

139. McConahay \& Hawley, Second Year, supra note 54, at 4 .

140. Id. at 4-5.

141. J. Ross, Does School Desegregation Work? A Quasi-Experimental Analysis of Parental Attitudes Toward the Effect of Desegregation on Student Achievement (Sept. 1977) (paper presented at the annual meeting of the Society for the Study of Social Problems) [hereinafter cited as Ross]. When the analysis of this research is completed, this will be the only quasi-experimental survey of parental attitudes on desegregation issues.

142. McConahay \& Hawley, Second Year, supra note 54.

143. Id. at 8-10; Rosss, supra note 141. 
"the difference in learning ability between most blacks and most whites is so great that neither group benefits from going to school together." ${ }^{144}$ On the other hand, among those supporting busing to achieve racial desegregation (overwhelmingly black), the proportion who believe that busing adversely affects the quality of education has gone from 32 to 22 percent and the proportion believing "the difference in learning ability between most blacks and most whites is so great that neither group benefits from going to school together," has decreased from 12 to 5 percent. ${ }^{145}$

In spite of this apparent polarization in views and increase in racial prejudice, a majority of whites surveyed in the Louisville study feel their relations with blacks in a variety of settings (for example, work, church, sporting events, and stores) are friendly or neutral, and there has been little change in this proportion. Moreover, there has been an increase since the first year of the plan in the proportion of whites believing that relations with blacks have improved in each of these areas. ${ }^{146}$

\section{Community Attitudes as Intervening Variables}

Community attitudes can significantly affect the process of school desegregation. Numerous studies have found strong positive relationships between parents' attitudes and those of their children. ${ }^{147}$ However, as children grow older, other influences grow stronger, so that by adolescence the relationship between the attitudes held by parents and those held by their children is much weaker. ${ }^{148}$ The Louisville-Jefferson County study included a survey of attitudes held by students in the fifth through twelfth grades. ${ }^{149}$ The results of this survey, given in Table 6, indicate that at the end of the first year of the desegregation plan (1976), almost identical proportions of black and white students supported the principle of racial balance. This was also true of the adult citizens surveyed. When the responses are categorized according to the place of residence of the students and adults surveyed (that is, whether they

144. Louis Harris and Associates Poll of Louisville-Jefferson County Citizens, 1977. This increase in racial prejudice may be attributable to a boomerang effect caused by the belief that the court order could be overturned as a result of the protest and violence surrounding implementation. Such an effect might be temporary, since it became evident the order would not be rescinded.

145. Id.

146. McConahay \& Hawley, Second Year, supra note 54, at 16-17.

147. Bird, Monachesi, \& Burdick, Infiltration and the Attitudes of White and Negro Parents and Children, 47 J. Abnormal \& Soc. Psych. 688 (1952) [hereinafter cited as Bird, Monchesi, \& Burdick]; Epstein \& Komorita, Childhood Prejudice as a Function of Parental Ethnocentrism, Punitiveness, and Outgroup Characteristics, $3 \mathrm{~J}$. Personality \& Soc. Psych. 259 (1966); Sartain, Attitudes of Parents and Children Towards Desegregation (1966) (unpublished doctoral dissertation, Vanderbilt University).

148. Bird, Monachesi, \& Burdick, supra note 147; Frenkel-Brunswik \& Havel, Prejudice in the Interviews of Children: Attitudes Toward Minority Groups, 82 J. Genetic Psych. 91 (1953).

149. McConahay \& Hawley, Preliminary Results, supra note 27. 
lived in the city or in the county) the effect remains, although it is not as strong as when the responses are categorized according to the race of the respondents.

\section{TABLE 6}

A Comparison of Student and Adult Responses to the Question, "Do You Think it is a Good or a Bad Idea for Children to go to Schools That Have about the Same Mix of Blacks and Whites as There is in the Louisville-Jefferson County Area?" by Race and Place of Residence

\begin{tabular}{|c|c|c|c|c|c|c|c|c|}
\hline & \multicolumn{2}{|c|}{ BLACKS } & \multicolumn{2}{|c|}{ WHITES } & \multicolumn{2}{|c|}{ CITY } & \multicolumn{2}{|c|}{ COUNTY } \\
\hline & Students & Adults & Students & Adults & Students & Adults & Students & Adults \\
\hline Good Idea & 90 & 90 & 52 & 51 & 69 & 63 & 52 & 51 \\
\hline Bad Idea & 10 & 6 & 38 & 40 & 27 & 30 & 37 & 39 \\
\hline Not Sure & 0 & 4 & 10 & 9 & 4 & 7 & 10 & 10 \\
\hline Total $\%$ & 100 & 100 & 100 & 100 & 100 & 100 & 100 & 100 \\
\hline
\end{tabular}

Source: Harris Poll, 1976, reported in J. McConahay and W. Hawley, Attitudes of Louisville and Jefferson County Public School Students Towards Busing for School Desegregation: Preliminary Results 7 (November, 1976) (Duke University Institute of Policy Sciences and Public Affairs); J. McConahay and W. Hawley, Attitudes of Louisville and Jefferson County Citizens Towards Busing for Public School Desegregation 4 (July, 1976) (Duke University Institute of Policy Sciences and Public Affairs).

This strong conformity between the attitudes of students and of adult citizens is not solely attributable to parental influence. Ninety percent of the white students whose parents opposed busing to achieve desegregation also opposed busing. On the other hand, only 44 percent of the white students whose parents favored busing to achieve desegregation also favored it. Seventy-nine percent of the black students whose parents favored busing also favored it, but only 47 percent of the black students whose parents opposed busing also opposed it. ${ }^{150}$ This suggests that there are strong environmental influences beyond the immediate family. Most whites in Louisville opposed busing for desegregation (91 percent); thus the children of those white parents who favor busing are exposed to environmental cross pressures that influence approximately half of them to conform to that social environment rather than to their parents' opinions. Most blacks in Louisville favored busing for desegregation (61 percent); thus the children of those blacks who opposed busing are exposed to environmental cross pressures that cause half of them to conform to that social environment, rather than to their parents' opinions.

It is also quite likely that there is an interaction between parents' attitudes and children's attitudes in this situation. That is, not only will a child be influenced by parental and social group opinions, but the attitudes of his or her

150. Louis Harris and Associates Poll of Louisville-Jefferson County students for Duke University Institute of Policy Sciences and Public Affairs. 
parent are likely to be reinforced or changed by the child's perception of his or her experience with desegregation. This in turn will influence the child's future perceptions. Thus there is likely to be a rather complex process of interaction that has never been analyzed in studies of the racial attitudes of children who attend desegregated schools or of the attitudes of their parents. Indeed, too many studies, by their failure to study this interaction, imply that children have no parents or community, and that parents have no children.

\section{Summary}

The research on community attitudes-all of which has been conducted in school districts experiencing extraordinarily high levels of protest and significant white flight-indicates that the following propositions characterize this phase of social change:

1. The reduction in school segregation has been followed by a reduction in racial intolerance in both the North and the South.

2. There is no backlash against the principle of racial integration despite racial confrontations and controversy surrounding school desegregation.

3. The prominence of the "busing problem" begins to recede by the end of the first year of the implementation of a school desegregation plan.

4. Although there is increasing support for the principle of racial integration and racially balanced schools, whites are overwhelmingly opposed to busing for racial desegregation of the schools.

5. Both blacks and whites greatly overestimate their neighbors' opposition to racial balance in the public schools.

6. In desegregated school systems, parents who have some children attending public school are more likely to intend to enroll their preschool children in the public schools than those whose children are all preschool age. In Boston, residents with school age children in areas affected by the first phase of desegregation were more likely to have a favorable evaluation of desegregation than those without school age children.

7. Even at the end of the second year of desegregation in school districts where there has been a great deal of violence and controversy associated with desegregation, there is increasing polarization over racial issues.

8. Parents continue to have strong fears regarding the quality of education in desegregated schools.

9. Most whites feel their relations with blacks are friendly or neutral despite the controversy over desegregation.

The research also indicates that both community and parental opinions have a strong influence on children's attitudes toward specific desegregation issues. 


\section{Voting Behavior and Residential INTEgRation}

In this final section, evidence supporting the assumption that desegregation of the schools will eventually bring about behavioral changes in other areas of community life is explored. Possibly, such additional behavioral changes are manifested earlier than attitudinal changes, since the symbolic elements of the controversy may result in individuals giving inconsistent responses because they are reacting to the controversy rather than the issue itself. Therefore, in this situation their behavior may actually reflect more positive change and more consistency than their expressed attitudes.

\section{A. Voting Behavior}

There is some evidence that antibusing candidates are not highly regarded, although people may vote for them initially. In a survey of the Detroit metropolitian area, about 68 percent of the white respondents agreed that "some political candidates have blown the busing issue out of proportion," and 57 percent believed that "most black and white children would do fine in school together if adults didn't stir up the situation." 151 This suggests there is a large contingent of whites who believe that school desegregation should not become an issue in local politics, and whose support for candidates who make it an issue would eventually fade.

Although there has been no systematic study of election campaigns that have occurred after a school desegregation plan has been implemented, some recent elections provide some insight into this question. In the school board elections held in Boston, ${ }^{152}$ in Charlotte-Mecklenburg, ${ }^{153}$ and in LouisvilleJefferson County ${ }^{154}$ two or three years after desegregation had been implemented, antibusing candidates were voted out of office and black candidates voted in. These three elections suggest that busing does become an old

151. Taylor, Public Reactions to a Court Order for Metropolitan School Desegregation: Detroit 1972, at 52 (1978) (unpublished paper, Institute for Research on Poverty, University of Wisconsin).

152. Three years after the Phase I plan had been implemented in Boston, Louise Day Hicks, John J. Kerrigan, and Pixie Palladino, the most infamous antibusing leaders in Boston, were voted out of office at the same time that John O'Bryant, the first black school board member, was voted into office in a city where blacks represent 20 percent of the population and elections are at large. It's No to Hicks, Kerrigan, Palladino, Galvin Plan, Boston Globe, Nov. 9, 1977, at 1, col. 3.

153. In the 1974 school board election in Charlotte-Mecklenburg, Sam McNinch, a prominent antibusing school board member, was defeated for re-election. Maniloff, Community Attitudes Toward a Desegregated School System (March 30, 1978) (paper presented at the annual meeting of the American Educational Research Association, Toronto, Canada).

154. The busing issue was no longer a campaign topic in Louisville-Jefferson County by the fall 1977 elections, two years after implementation of the school desegregation plan. Todd Hollenbach, the incumbent county executive and author of a voluntary alternative to the mandatory desegregation plan, was defeated by a Republican candidate who was considered more liberal on that issue. Louisville-Courier J., Nov. 9, 1977, at 1, col. 1. 
issue and that antibusing candidates are eventually defeated. There are numerous plausible, but unprovable, explanations for this. First, the surveys extend no further than the end of the second year of desegregation, whereas the election reversals begin to occur in the third year. It may take that long for attitudes to begin to change. Assuming no change in attitude, it is possible that these election outcomes indicate the aspirations of whites, while the surveys represent their "realistic" assessment of the current situation and their reaction to the controversy. In other words, whites may be saying that busing at this point in time does not work the way it should, but it might if the politicians would stop "stirring things up." It may also be that school desegregation has caused whites to be more sensitive to the issue of black representation. Of course, in the absence of voter surveys or precinct analyses, such explanations are obviously speculative.

\section{B. Residential Integration}

The hypothesis that school desegregation will lead to community integration is contingent on a reduction in prejudice. It is, however, also based on the fact that extensive, citywide desegregation will include reassignments away from the neighborhood school because the neighborhood attendance zone is residentially segregated. Thus a family can avoid busing if it lives in an integrated area. Moreover, the fact that changing neighborhoods will have their schools racially stabilized under a citywide plan may provide an incentive for some white families to remain in such neighborhoods. Realistically, these changes are not expected to be large, given the amount of movement that occurs normally within a city, but because the incentives are clear and obvious, this effect may appear before many others.

Unfortunately, it is not really feasible to analyze the relationship between school desegregation and residential desegregation at the aggregate level, because the most up-to-date source of data is the 1970 census. Only a few citywide plans were implemented prior to 1970 , and these were at the end of the decade rather than at the beginning. Although these school districts exhibit a fairly large reduction in segregation, almost twice as much on the average as other school districts, one cannot satisfactorily differentiate cause and effect. A systematic aggregate analysis will probably have to wait for the 1980 census. Even then, if the effects are small they could be swallowed up at the school district level.

There is some scattered evidence on this point in a few case studies. A study done in the Riverside school district found fifty black families who had moved into white neighborhoods to be near their child's new school. ${ }^{155} \mathrm{~A}$

155. Greenwood, School Desegregation-Successes, Failures, Surprises, Los Angeles Times, May 21 , 1972, at 1 , col. 3 . 
rather compelling documentation of this phenomenon is provided by the Kentucky Commission on Human Rights. ${ }^{156}$ The Louisville-Jefferson County school district experienced little white out-migration (perhaps because it is a countywide district). Nevertheless the number of black pupils residing within the city limits declined by 892 and increased by 2,503 in the suburban county (still within the school district) between 1974, the year before the plan was implemented, and 1977, the end of the second year of school desegregation. This increase is greater than in the entire twelve year period preceding 1974. Pupil enrollment data indicate that 86 percent of the increase in black students outside the city of Louisville took place in areas where blacks are exempt from busing because they are in a minority and live in desegregated residential areas.

While it is difficult to determine motives without a survey, there are some significant features of the Louisville-Jefferson County desegregation plan that suggest an explanation. First, under the terms of the plan, any student who lives in a school attendance district in which he or she is in the racial minority is exempt from being reassigned away from that school. ${ }^{157}$ Second, in 1975 the East End in suburban Jefferson County distributed pamphlets aimed at black homeseekers encouraging them to move into that area, presumably in order to integrate those schools "naturally" and avoid busing. ${ }^{158}$

\section{Summary}

The evidence from these studies indicates there may be some significant changes in the behavior of citizens in a community after its schools have been desegregated. Indeed, this may appear before any consistent attitudinal changes are perceived.

1. Black candidates are voted into office, and antibusing candidates defeated two to three years after implementation of a school desegregation plan.

2. The evidence from two case studies of districts with citywide busing plans suggests that these plans motivate black families to move into white neighborhoods to be near the school to which their children have been assigned in order to avoid busing.

156. Foushee \& Hamilton, Housing Desegregation Increases as Schools Desegregate in Jefferson County (1977) (unpublished paper, Kentucky Commission on Human Rights, Louisville, Kentucky).

157. This point was emphasized in a pamphlet distributed by the U.S. Commission on Civil Rights, which listed the Jefferson County schools where blacks would be exempt from busing if they moved into the neighborhood. U.S. Comm'n on Civil Riguts, Six Ways to Avoin Busing (November 1975).

158. Foushee \& Hamilton, supra note 156. 


\section{Conclusion}

The research findings concerning the community impact of school desegregation are, with the exception of the research on white flight, based on only a small number of studies. Furthermore, the research on attitudes has been conducted only in communities that underwent extensive protest, violence, and white flight when they desegregated. Thus, how variations in the first phase of social change (the reaction to the decision) affect variations in the second phase of social change (the reduction in prejudiced attitudes and behavior) is not fully understood at present.

The evidence on protest demonstrations indicates that protest is primarily a function of (1) the characteristics of the desegregation plan (particularly whether whites are bused into black neighborhoods) and (2) a supportive neighborhood environment. Furthermore, a reasonable assumption is that the first condition contributes to the second. The greater the proportion of whites reassigned to schools in black neighborhoods, the more likely it is that entire white neighborhoods will be affected and thus united in opposition. Although protest demonstrations and protest voting rarely occur after the implementation year, and are not successful in preventing desegregation once the decision has been made, demonstrations can have serious consequences for student outcomes, either directly through their effect on attendance and inschool behavior, or indirectly through their effect on white flight and polarization of attitudes.

From a practical standpoint, perhaps no issue is more important than behavioral compliance-obviously there can be no desegregation if all the whites have left the school system. The research suggests there are certain implementation year costs that particular characteristics of a desegregation plan and of a school district can maximize or minimize. On the average, a city school system less than 35 percent black can expect to lose 5 percent of its white enrollment with an average two-way desegregation plan (30 percent blacks, 5 percent whites reassigned, and a reduction in segregation of -30 ) and nine percent of its white enrollment with the most extensive plan (60 percent blacks, 25 percent whites reassigned, and a reduction in segregation of -67). City school systems with 35 percent or more black students can expect to lose 8 percent of their white school enrollment with the average desegregation plan and 14 percent with the most extensive plan. Since the net gain in interracial contact (the proportion white in the average black child's school) for these school systems is substantial-an additional 17 percent (under the average plan) or 20 percent (under the extensive plan) in school systems less than 35 percent black and an additional 21 percent (under the average plan) or 25 percent (under the extensive plan) in school system with 35 percent or more black students, it is obvious that at the simple level of "mix- 
ing" blacks with whites, school desegregation is quite successful. Furthermore, the significant increase in interracial contact in desegregated school districts, compared to that in nondesegregated school districts, continues for as long as ten years after school desegregation has been implemented.

On the basis of these findings, it might be argued that the implementation year enrollment loss due to desegregation is not significant, since eventually it will be compensated for by less than normal postimplementation losses. Moreover, all desegregation plans show a substantial net gain in interracial contact regardless of the amount of white flight associated with desegregation. However, neither the long-term effect of desegregation on the class composition of the school system, nor the relationship of white flight in the implementation year to future attitudinal change is known. Until this information is available, it would seem prudent for policymakers to attempt to minimize the costs associated with implementation.

The success of school desegregation in achieving positive attitudinal and behavioral changes in adults residing in the desegregated community is mixed. The national attitudinal surveys show increasing racial tolerance, apparently in direct relation to school desegregation. Although it is conceivable that the causal variable is not the reduction in school segregation, but some third variable causing both changes, this research clearly demonstrates that there is no national backlash in response to the rapid and forced desegregation of this decade with regard to the principle of desegregation.

My assessment of the results of the community attitudinal surveys is that the protest and violence associated with desegregation in these communities has delayed the anticipated positive attitudinal change. Although there is positive attitudinal change on some issues, this is offset by increased polarization and prejudiced attitudes on other issues. I predict that there will be no significant attitudinal change until the school desegregation plan is perceived as irrevocable and the element of force is forgotten. Indeed, one possible reason why the national surveys have more optimistic findings than the community surveys is that they include respondents from communities that have desegregated as much as six or seven years earlier.

One positive effect, which is observed sooner than attitude change, is the change in adult behavior. The evidence from three case studies suggests that voting behavior changes significantly about three years after desegregation. Antibusing candidates are voted out of office and black candidates voted in by a significant proportion of the white voters.

Moreover, two case studies suggest that busing for school desegregation increases residential desegregation because black parents move to the neighborhood in which their children's new school is located. Apparently, both black and white parents see this as a way to avoid busing by "naturally" integrating the neighborhood school. Although there is now no evidence to 
support the assumption, whites in racially changing neighborhoods will probably remain in such neighborhoods longer because the proportion of black students in their neighborhood school is reduced and racial balance is guaranteed. The effect of such individual household movements on the aggregate level of residential integration cannot now be determined, although the school districts with the greatest increase in school desegregation between 1960 and 1970 also had the greatest increases in residential integration.

Thus, from a policy standpoint, the costs of school desegregation seem small, with school desegregation quite successful in achieving the instrumental goal of interracial contact. Nevertheless, in the communities studies, it has not had much short term success in achieving consistently positive attitudinal changes. On the assumption that these changes will not occur until after the forced aspect of desegregation has been forgotten, it could be argued that only voluntary desegregation plans should be implemented. Unfortunately, voluntary plans do not produce any significant desegregation and thus, if the primary goal is interracial contact, students will have to be reassigned on a mandatory basis. 
